\title{
Microstructural Characteristics of AlSi9Cu3(Fe) Alloy with High Melting Point Elements
}

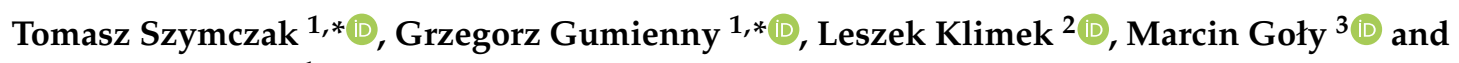 \\ Tadeusz Pacyniak $^{1}$ \\ 1 Department of Materials Engineering and Production Systems, Lodz University of Technology, \\ 90-924 Lodz, Poland; tadeusz.pacyniak@p.lodz.pl \\ 2 Institute of Materials Science and Engineering, Lodz University of Technology, 90-924 Lodz, Poland; \\ leszek.klimek@p.lodz.pl \\ 3 Department of Physical \& Powder Metallurgy, AGH University of Science and Technology, \\ 30-059 Krakow, Poland; marcing@agh.edu.pl \\ * Correspondence: tomasz.szymczak@p.lodz.pl (T.S.); grzegorz.gumienny@p.lodz.pl (G.G.); \\ Tel.: +48-426312276 (T.S.); +48-426312264 (G.G.)
}

Received: 18 August 2020; Accepted: 21 September 2020; Published: 23 September 2020

\begin{abstract}
The paper presents the results of microstructure tests of EN AC-46000 hypoeutectic Al-Si alloy with and without high-melting-point elements: chromium, molybdenum, vanadium, and tungsten. The above-mentioned elements were used individually or simultaneously in various combinations. The tested castings were made using two technologies: shell molding and high pressure die casting (HPDC). Using X-ray diffraction and microanalysis of the chemical composition an attempt to determine the phase structure of the tested alloy was made. It has been shown that the microstructure of the base alloy consists of dendrites of $\alpha(\mathrm{Al})$ solid solution and complex eutectic mixtures: ternary $\alpha(\mathrm{Al})+\mathrm{Al}_{15}(\mathrm{Fe}, \mathrm{Mn})_{3} \mathrm{Si}_{2}+\beta(\mathrm{Si})$ and quaternary $\alpha(\mathrm{Al})+\mathrm{Al}_{2} \mathrm{Cu}+\mathrm{AlSiCuFeMgMnNi}$ $+\beta(\mathrm{Si})$. High-melting point elements, regardless of the combination used, attach mainly to intermetallic phases rich in $\mathrm{Fe}$ and form the $\mathrm{Al}_{15}(\mathrm{Fe}, \mathrm{Mn}, \mathrm{M})_{3} \mathrm{Si}_{2}$ phase, where $\mathrm{M}$ is any high melting point element or a combination of such elements. It has been shown that the area fraction of the above-mentioned phase increases with increasing content of high melting point elements. A greater area fraction of the $\mathrm{Al}_{15}(\mathrm{Fe}, \mathrm{Mn}, \mathrm{M})_{3} \mathrm{Si}_{2}$ phase in the casting from the shell mold in relation to the high pressure die casting has been also found.
\end{abstract}

Keywords: multicomponent Al-Si alloys; microstructure; high pressure die casting (HPDC); thermal analysis

\section{Introduction}

Among the many aluminum alloys AlSi9Cu3(Fe) (EN AC-46000) is a typical high pressure die casting alloy. According to the PN EN 1706 standard [1], its chemical composition is as follows: 8.0-11.0 wt \% Si; $\leq 1.3 \mathrm{wt} \% \mathrm{Fe} ; 2.0-4.0 \mathrm{wt} \% \mathrm{Cu} ; \leq 0.55 \mathrm{wt} \% \mathrm{Mn} ; 0.05-0.55 \mathrm{wt} \% \mathrm{Mg} ; \leq 0.15 \mathrm{wt} \% \mathrm{Cr}$; $\leq 0.55 \mathrm{wt} \% \mathrm{Ni} ; \leq 1.2 \mathrm{wt} \% \mathrm{Zn} ; \leq 0.35 \mathrm{wt} \% \mathrm{~Pb} ; \leq 0.15 \mathrm{wt} \% \mathrm{Sn}, \leq 0.25 \mathrm{wt} \%$ Ti. The ASTM equivalent of the above mentioned alloy is A380. The crystallization process of this alloy is described in [2] by Taylor et al. First dendrites of $\alpha(\mathrm{Al})$ solid solution crystallize out of the liquid. Then, as a result of the peritectic transformation, the lamellar intermetallic phase $\beta-\mathrm{Al}_{5} \mathrm{FeSi}$ is formed, and afterwards three eutectic mixtures crystallize successively: $\alpha(\mathrm{Al})+\beta(\mathrm{Si})$ eutectic mixture and two complex mixtures containing $\mathrm{Mg}_{2} \mathrm{Si}$ and $\mathrm{Al}_{2} \mathrm{Cu}$ phases. On the other hand, in [3], the authors present the three-stage process of EN AC-46000 alloy crystallization based on the derivative and thermal analysis. According to the presented data, the crystallization process starts with the crystallization of $\alpha(\mathrm{Al})$ 
dendrites, then two complex eutectic mixtures crystallize: ternary and quaternary. The ternary eutectic consists of solid solutions $\alpha(\mathrm{Al}), \beta(\mathrm{Si})$, and the Fe-rich intermetallic phase. The quaternary eutectic mixture consists of solutions: $\alpha(\mathrm{Al})$ and $\beta(\mathrm{Si}), \mathrm{Al}_{2} \mathrm{Cu}$ intermetallic phase and the phase described as AlSiCuFeMgMnNiTi. In [4], Dinnis et al. report that the addition of $0.5 \mathrm{wt} \% \mathrm{Mn}$ results in the occurrence of the $\mathrm{Al}_{15}(\mathrm{Fe}, \mathrm{Mn})_{3} \mathrm{Si}_{2}$ intermetallic phase with the morphology of "Chinese writing" instead of the Fe-rich $\beta-\mathrm{Al}_{5} \mathrm{FeSi}$ phase. The presence of the $\beta-\mathrm{Al}_{5} \mathrm{FeSi}$ phase negatively affects the tensile strength and elongation [2]. The $\mathrm{Al}_{15}(\mathrm{Fe}, \mathrm{Mn})_{3} \mathrm{Si}_{2}$ phase is assigned a less detrimental effect on the aforementioned properties [2]. The papers [5-7] present the results of the HPDC hypoeutectic alloy microstructure. The data presented therein shows the presence of $\alpha(\mathrm{Al})$ solid solution dendrites, $\alpha(\mathrm{Al})+\beta(\mathrm{Si})$ eutectic mixture, $\mathrm{Al}_{2} \mathrm{Cu}$ and iron-rich intermetallic phases in the microstructure. These phases, depending on the concentration of $\mathrm{Fe}, \mathrm{Mn}$, and $\mathrm{Cr}$, can be characterized by a different phase structure and morphology. The $\beta-\mathrm{Al}_{5} \mathrm{FeSi}$ phase crystallizes in the alloy with a relatively low manganese and chromium content. At $0.15 \mathrm{wt} \% \mathrm{Mn}$ or more, $\mathrm{Al}_{15}(\mathrm{Fe}, \mathrm{Mn})_{3} \mathrm{Si}_{2}$ phase appears in the microstructure. If $0.15 \mathrm{wt} \%$ chromium is present in the alloy, its atoms are attached to this phase. The authors of [5] describe such a phase as $\alpha-\mathrm{Al}_{x}(\mathrm{Fe}, \mathrm{Mn}, \mathrm{Cr})_{y} \mathrm{Si}_{z}$, while in [7] it described as $\mathrm{Al}_{15}(\mathrm{Fe}, \mathrm{Mn}, \mathrm{Cr})_{3} \mathrm{Si}_{2}$. Fe-rich phases in HPDC alloys may be characterized by plate, block or polyhedral morphology, depending on $\mathrm{Fe}, \mathrm{Mn}$, and $\mathrm{Cr}$ concentrations and casting parameters. The authors of [7] report the possibility of the $\mathrm{Al}_{5} \mathrm{Si}_{6} \mathrm{Mg}_{8} \mathrm{Fe}_{2}$ intermetallic phase crystallization in the above-mentioned alloy. The content of Fe and $\mathrm{Mn}$ is also significantly related to the phenomenon of die soldering $[5,8,9]$. This phenomenon consists in the formation of intermetallic phases on the surface of the pressure die casting mold, mainly in the Al-Fe and $\mathrm{Al}-\mathrm{Fe}-\mathrm{Si}$ systems, as a result of the reaction of the liquid Al-Si alloy with the mold material. This leads to the casting sticking to the mold surface and significantly accelerates its wear. The method of preventing die soldering is to increase the content of Fe and $\mathrm{Mn}$ in the alloy. According to [5], the Fe content sufficient to protect the mold is $0.8 \mathrm{wt} \%$. According to [8], the mold can be secured with $1.1 \mathrm{wt} \% \mathrm{Fe}$, and the lower Fe content can be compensated by the addition of $\mathrm{Mn}$.

High-melting-point elements can also affect the formation of intermetallic phases in aluminum alloys. In addition to the aforementioned $\mathrm{Cr}$, other elements from this group are also analyzed in this paper: Mo, V, and W. A small number of studies concerning high-melting point elements in Al-Si alloys have revealed two main purposes for using them: the increase in the effect of precipitation strengthening and reducing the detrimental effect of iron on the mechanical properties. It has been shown that $\mathrm{Cr}$, Mo, or $\mathrm{V}$ can enhance the precipitation hardening effect, consequently increasing the mechanical properties at both ambient and elevated temperatures [10-13]. Chromium and molybdenum are the most effective in this respect. The ability to reduce the detrimental effect of iron on the mechanical properties of Al-Si alloys is demonstrated by $\mathrm{Cr}, \mathrm{Mo}, \mathrm{V}$, and $\mathrm{W}$. The aforementioned elements cause a reduction in the size of the $\beta-\mathrm{Al}_{5} \mathrm{FeSi}$ lamellar precipitates or crystallization instead of the lamellar phase the other phases with a morphology considered to be less harmful. Morphological changes having a beneficial effect on the mechanical and plastic properties of Al-Si alloy caused by Cr, Mo, V, and W (added separately) have been described in $[5,10,14-16]$. Depending on the type and amount of high-melting point elements as well as the crystallization conditions, the iron-rich phases may have different morphology: "Chinese writing", block, polygon, star, or dendritic. The above-described morphological changes were analyzed mainly in the microstructure of die castings. It has been shown that these changes can positively affect the mechanical properties of aluminum alloys. However, the cheaper manganese is most often used as the main additive in reducing the detrimental effect of iron.

The analysis of the $\mathrm{Cr}, \mathrm{Mo}, \mathrm{V}$, and $\mathrm{W}$ interactions in hypoeutectic aluminum alloy was developed on the basis of the two-component Al-Si phase diagrams with the above mentioned elements as well as the phase diagrams between the tested high-melting point elements. The Al-Mo [17] and Al-W [18] phase diagrams show that molybdenum and tungsten are not soluble in solid aluminum. In [19], Okamoto reports that also chromium does not dissolve in aluminum. However, according to [18], the maximum solubility of $\mathrm{Cr}$ in $\mathrm{Al}$ occurs at the temperature of $661.5^{\circ} \mathrm{C}$ and amounts to $0.71 \mathrm{wt} \%$. The Al-V phase diagram [18] shows that the solubility of vanadium in aluminum amounts to a 
maximum of $0.6 \mathrm{wt} \%$. The lack of solubility of the above-mentioned high-melting point elements in $\mathrm{Al}$ or their highly limited solubility causes the precipitation of a number of intermetallic phases. According to the phase diagrams, they crystallize mainly as a result of peritectic transformations. Also, the Cr-Si [18], Mo-Si [20], V-Si [21], and W-Si [22] phase diagrams show the possibility of the formation of numerous intermetallic phases. All these elements practically do not dissolve in silicon. Instead, they show excellent mutual solubility in the solid state. The phase equilibrium systems Cr-Mo [23], Cr-V [24], Cr-W [25], Mo-V [26], Mo-W [18], and V-W [27] show that they form unlimited solutions. The presented analysis of the interaction of $\mathrm{Cr}, \mathrm{Mo}, \mathrm{V}$, and $\mathrm{W}$ in aluminum alloys shows the possibility of crystallization of numerous intermetallic phases. From the point of view of mechanical properties, the intermetallic phases can increase the hardness of the alloy and thus its brittleness. The papers [28-30] present the results of a statistical analysis of the effect of $\mathrm{Cr}, \mathrm{Mo}, \mathrm{V}$, and $\mathrm{W}$ in the HPDC aluminum alloy on its mechanical properties (tensile strength, yield point, elongation, and hardness). They show the possibility of increasing the above mentioned properties by the high melting point elements. The authors attribute this possibility to supersaturation of the $\alpha(\mathrm{Al})$ solid solution with high melting point elements. The possibility of the crystal supersaturation with the substance at the front of its crystallization increases with the increase of the nucleation rate and crystal growth [31,32]. Another factor that significantly influences the possibility of supersaturation of the crystal is the amount of the dissolved substance ahead of the crystallization front. It was reported in [33] that the supersaturation of the $\alpha(\mathrm{Al})$ phase is the greater the greater amount of the dissolved substance ahead of the crystallization front. It follows from the above that the supersaturation of the dendrite with the high melting point elements will be more effective the faster the heat transfer from the casting and the higher the concentration of admixtures (including $\mathrm{Cr}, \mathrm{Mo}, \mathrm{V}$, and $\mathrm{W}$ ) at the front of dendrite crystallization. A relatively high rate of heat transfer from the casting can be ensured by the use of technology that uses a steel mold, such as die casting and, in particular, high pressure die casting (HPDC). However, to assess the amount of high melting point elements on the dendrite crystallization front, it is important to learn about the crystallization processes and the formation of aluminum alloy microstructure with the different content of these elements.

This paper presents the changes in the microstructure of multi-component Al-Si alloy on the example of EN AC-46000 alloy occurring as a result of $\mathrm{Cr}, \mathrm{Mo}, \mathrm{V}$, and $\mathrm{W}$ additions in various amounts and combinations.

\section{Materials and Methods}

The range of the chemical composition of the base EN AC-46000 alloy used for the tests has been shown in Table 1. The range of the chemical composition given is determined based on the spectrometric examination of 15 specimens of the base alloy.

Table 1. Range of the chemical composition of the base EN AC-46000 alloy used for the tests.

\begin{tabular}{ccccccccc}
\hline \multicolumn{7}{c}{ Chemical Composition, wt \% } \\
\hline $\mathbf{S i}$ & $\mathbf{C u}$ & $\mathbf{Z n}$ & $\mathbf{F e}$ & $\mathbf{M g}$ & $\mathbf{M n}$ & $\mathbf{N i}$ & $\mathbf{T i}$ & $\mathbf{A l}$ \\
\hline $8.69 \div 9.35$ & $2.09 \div 2.43$ & $0.90 \div 1.07$ & $0.82 \div 0.97$ & $0.21 \div 0.32$ & $0.18 \div 0.25$ & $0.05 \div 0.13$ & $0.042 \div 0.049$ & al. \\
\hline
\end{tabular}

The base alloy was melted in a gas-fired shaft furnace type MH II-N 1500/750 by StrikoWestofen (Gummersbach, Germany). Inside the melting furnace, the alloy was refined with the Ecosal Al113.S solid refiner. After smelting and refining, the alloy was deslagged and transported to a holding furnace located at a high pressure die casting machine. The following high melting point elements were added to the base alloy in the holding furnace: $\mathrm{Cr}, \mathrm{Mo}, \mathrm{V}$, and $\mathrm{W}$. These elements were added in various combinations: singly, in double and triple combinations as well as simultaneously. Due to the relatively high melting point of $\mathrm{Cr}, \mathrm{Mo}, \mathrm{V}$, and $\mathrm{W}$ and the relatively low alloy temperature in the holding furnace $\left(\sim 750{ }^{\circ} \mathrm{C}\right)$, these elements were added in the form of master alloys: AlCr15, AlMo8, AlV10, and AlW8. Master alloys containing high-melting point elements were in the form of pieces weighing about $200 \mathrm{~g}$. 
The holding time of the master alloys in the furnace at the temperature of $750{ }^{\circ} \mathrm{C}$ was $30-40 \mathrm{~min}$. The used combinations, the content of the high-melting elements in a given combination and the step (how the concentration of high-melting point elements was changed) are presented in Table 2. The real tested content of high-melting point elements were within the range of $\pm 0.015 \mathrm{wt} \%$ in relation to those indicated in Table 2 nominal values. If more than one high melting point element was added, all the elements were used in equal amount.

Table 2. Content of high melting point elements in the tested alloys.

\begin{tabular}{|c|c|c|c|}
\hline \multicolumn{2}{|c|}{ Combinations of High Melting Point Elements } & Content Range, wt \% & Step, wt \% \\
\hline Single elements & $\begin{array}{c}\mathrm{Cr} \\
\mathrm{Mo} \\
\mathrm{V} \\
\mathrm{W}\end{array}$ & $0.0 \div 0.5$ & \multirow[b]{2}{*}{0.1} \\
\hline Double combinations & $\begin{array}{c}\text { Cr, Mo } \\
\text { Cr, V } \\
\text { Cr, W } \\
\text { Mo, V } \\
\text { Mo, W } \\
\text { V, W }\end{array}$ & $0.0 \div 0.4$ each & \\
\hline Triple combinations & $\begin{array}{c}\text { Cr, Mo, V } \\
\text { Mo, V, W } \\
\text { Cr, V, W } \\
\text { Cr, Mo, W }\end{array}$ & \multirow[t]{2}{*}{$0.00 \div 0.25$ each } & \multirow[t]{2}{*}{0.05} \\
\hline Simultaneously & Cr, Mo, V, W & & \\
\hline
\end{tabular}

For each variant of the chemical composition, pressure and shell castings were made. The pressure castings were in the shape of the side cover of the roller shutter casing, approximately $2 \mathrm{~mm}$ thick. They were manufactured on a cold-chamber die casting machine Idra 700S (IDRA, Travagliato, Italy). The shell mold, on the other hand, was made of a shell sand, it had the form of a probe, the dimensions of which are presented in [3]. A thermal and derivative analysis of the crystallization process of the tested alloys was carried out with the use of a above mentioned probe equipped with a PtRh10-Pt thermocouple. Thermal and derivative analysis is a universal method of studying the solidification of alloys. So far, it has been successfully used to study alloys: iron [34], aluminum [35,36], copper [37], magnesium [38], or cobalt [39]. The alloy temperature at the time of pouring the probe was $\sim 1000{ }^{\circ} \mathrm{C}$.

Metallographic tests were carried out on specimens taken from high pressure die castings as well as the from the shell mold. The metallographic specimens were etched with a $2 \%$ aqueous solution of hydrofluoric acid. The microstructure was examined using the Nikon Eclipse MA200 optical microscope (Nikon, Tokyo, Japan) and the Hitachi S-3000N scanning electron microscope (SEM) (Hitachi, Tokyo, Japan). The NIS Elements image analysis software (version 3.00, Japan) was used to determine the area fraction of intermetallic phases.

X-ray diffraction was performed on a Bruker D8 Advance diffractometer (Bruker, Karlsruhe, Germany). Filtered radiation of a cobalt lamp with a wavelength of $\lambda=0.179 \mathrm{~nm}$ was used. Phase analysis was performed using EVA software. Patterns from the ICDD (The International Center Diffraction Data) database were used. The point microanalysis of the element concentration and the map of the surface distribution were made using a HITACHI S-3000N scanning electron microscope (Hitachi, Tokyo, Japan) equipped with an EDS detector by Pionieer and the VENTAGE software by NORAN. The acceleration voltage was $15 \mathrm{keV}$. 


\section{Results}

\subsection{Base Alloy}

The three-stage process of crystallization of the base alloy is illustrated by the thermal and derivative analysis curves (black color) presented in Figure 1.

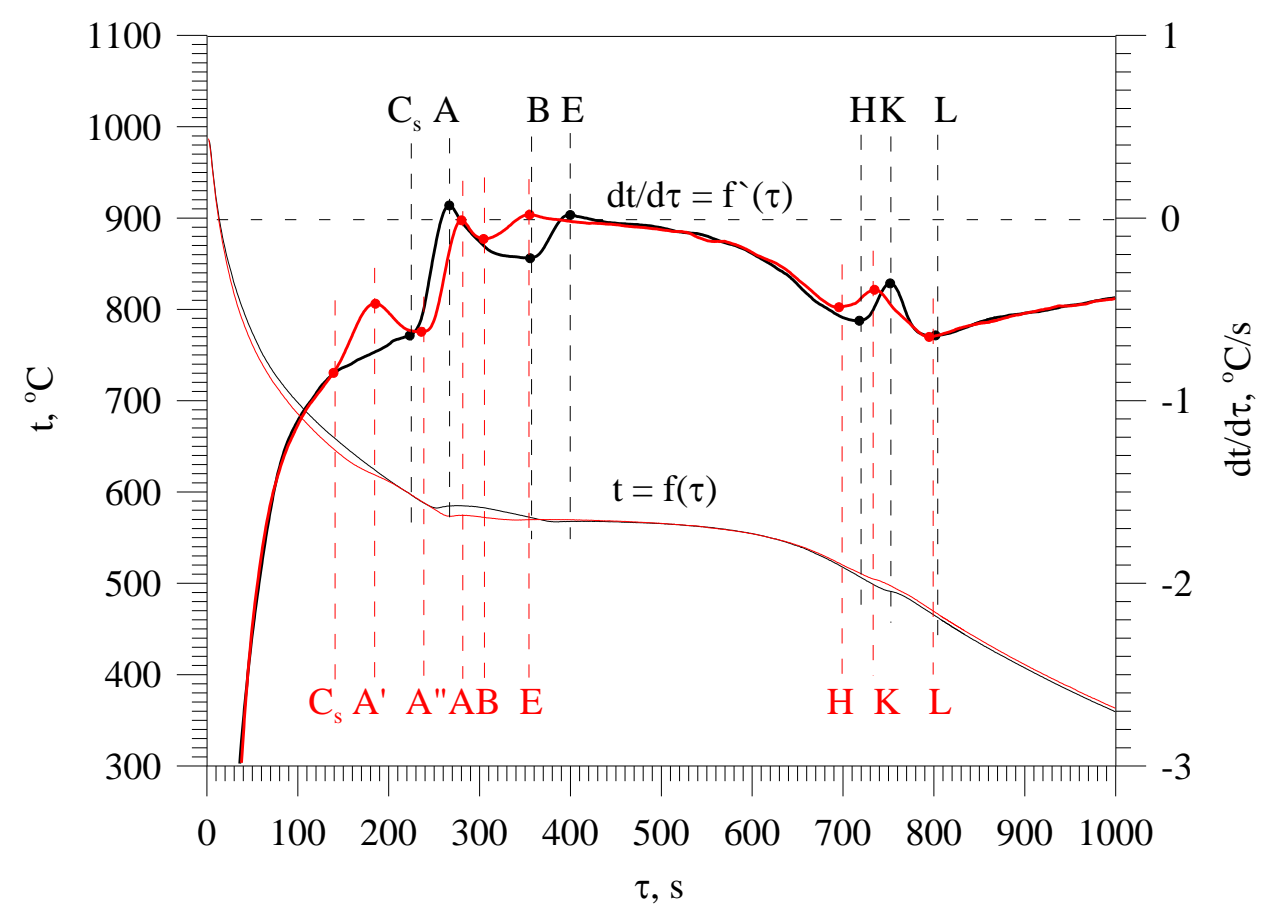

Figure 1. Thermal and derivative analysis curves of the base alloy (black color) and containing $0.20 \mathrm{wt} \%$ Cr, Mo, V, and W (red color).

The derivative curve shows three thermal effects: $C_{s} A B, B E H$, and HKL. According to the data presented in [3], these are the effects caused by the crystallization of $\alpha(\mathrm{Al})$ solid solution, ternary eutectic $\alpha(\mathrm{Al})+\mathrm{Al}_{15}(\mathrm{Fe}, \mathrm{Mn})_{3} \mathrm{Si}_{2}+\beta(\mathrm{Si})$ and quaternary eutectic $\alpha(\mathrm{Al})+\mathrm{Al}_{2} \mathrm{Cu}+\mathrm{AlSiCuFeMgMnNi}+\beta(\mathrm{Si})$. The authors of [40-42] show that in the case of multicomponent hypoeutectic al-Si alloys, after the crystallization of the primary $\alpha(\mathrm{Al})$ phase, complex eutectic mixtures usually crystallize, in which the $\alpha(\mathrm{Al})$ and $\beta(\mathrm{Si})$ solid solutions and intermetallic phases appear as component phases. The average solidification rate was $0.23{ }^{\circ} \mathrm{C} / \mathrm{s}$ for the base alloy, and $0.27^{\circ} \mathrm{C} / \mathrm{s}$ for the alloy containing $0.20 \mathrm{wt} \%$ of all high-melting point elements (red color, Figure 1). The microstructure of the base aluminum alloy from the shell mold is shown in Figure 2. This microstructure is consistent with the results of the thermal and derivative analysis. The component phase of the ternary eutectic marked in the figure is the iron-rich $\mathrm{Al}_{15}(\mathrm{Fe}, \mathrm{Mn})_{3} \mathrm{Si}_{2}$ phase. This is indicated by the morphology of "Chinese writing" characteristic of this phase and the results of the point analysis of the chemical composition. The studied precipitation with a histogram of the elements concentration is shown in Figure $3 a, b$. The occurrence of this phase in the microstructure of EN AC-46000 alloy was also found in [5,6,43-45]. In [6], the authors also state the possibility of the occurrence of another iron-rich intermetallic phase- $\beta-\mathrm{Al}_{5} \mathrm{FeSi}$. 


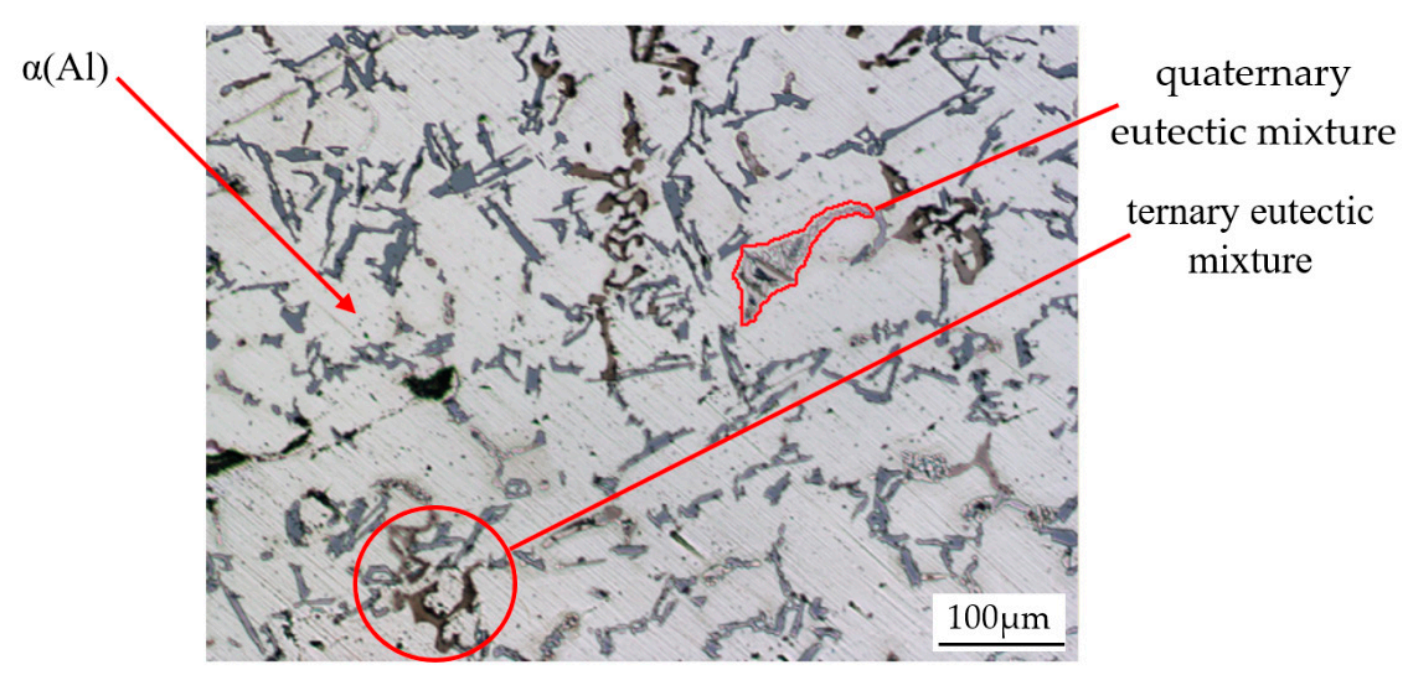

Figure 2. Microstructure of the base Al-Si alloy in the casting from the shell sand probe: $\alpha, \alpha+$ $\mathrm{Al}_{15}(\mathrm{Fe}, \mathrm{Mn})_{3} \mathrm{Si}_{2}+\beta, \alpha+\mathrm{Al}_{2} \mathrm{Cu}+\mathrm{AlSiCuFeMnMgNi}+\beta$.

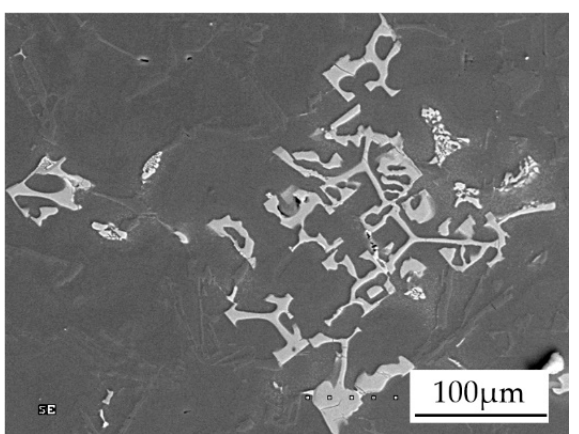

(a)

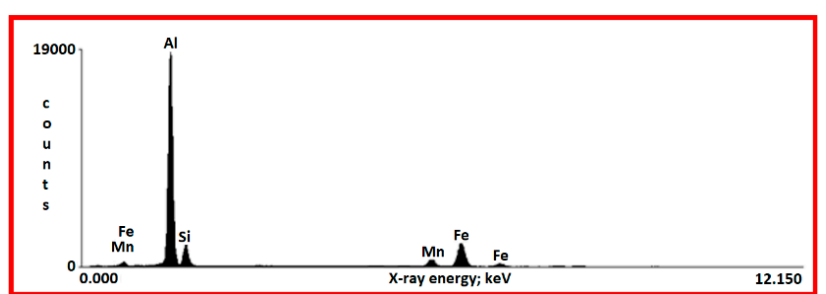

(b)

Figure 3. Precipitation of $\mathrm{Al}_{15}(\mathrm{Fe}, \mathrm{Mn})_{3} \mathrm{Si}_{2}$ phase (a) with a histogram of the concentration of the constituent elements (b).

The presence of the $\mathrm{Al}_{2} \mathrm{Cu}$ phase within the quaternary eutectic was determined by X-ray diffraction. Figure 4 also shows the presence of $\alpha(\mathrm{Al})$ and $\beta(\mathrm{Si})$ solid solutions in the tested alloy. The symbol of the AlSiCuFeMgMnNi phase in the quaternary eutectic should be treated conventionally, because it does not mean the intermetallic phase containing all the elements, but a number of phases that can contain these elements. Such a situation is possible due to the high complexity of the chemical composition of the tested alloy. The 'pushing' of the elements characterized by reverse microsegregation by the crystallization front of the $\alpha(\mathrm{Al})$ phase and the ternary eutectic may lead to different chemical composition of the residual liquid in different regions of the alloy. Then, in quaternary eutectic, fine intermetallic phases with different chemical composition and phase structure can crystallize. Figure 5 shows, for example, the region of the quaternary eutectic and the map of $\mathrm{Al}, \mathrm{Si}, \mathrm{Mg}$, and $\mathrm{Cu}$ distribution. 


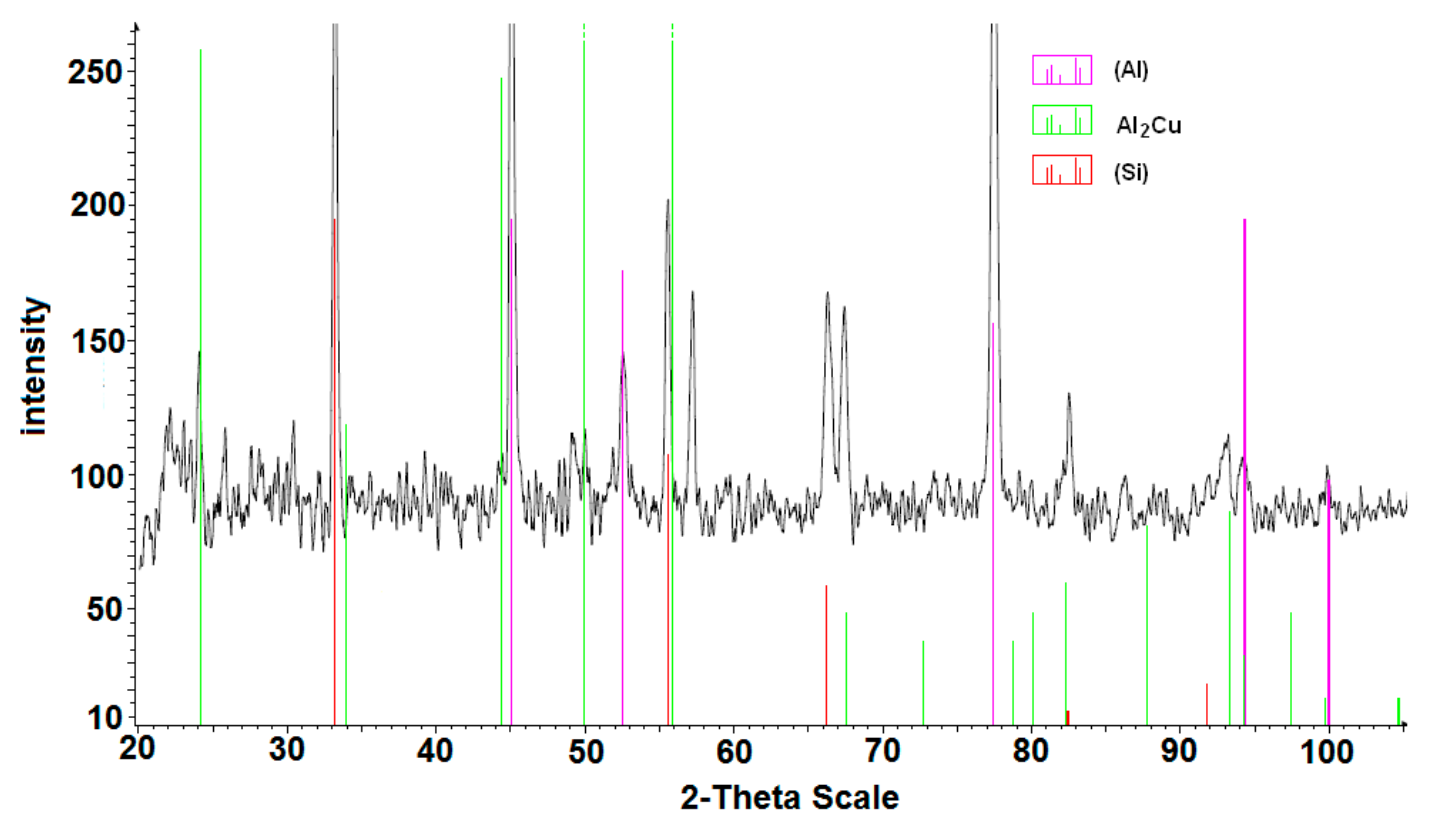

Figure 4. X-ray diffraction pattern for phase identification in the base alloy from the shell mold, identified phases: $\alpha(\mathrm{Al}), \mathrm{Al}_{2} \mathrm{Cu}, \beta(\mathrm{Si})$.

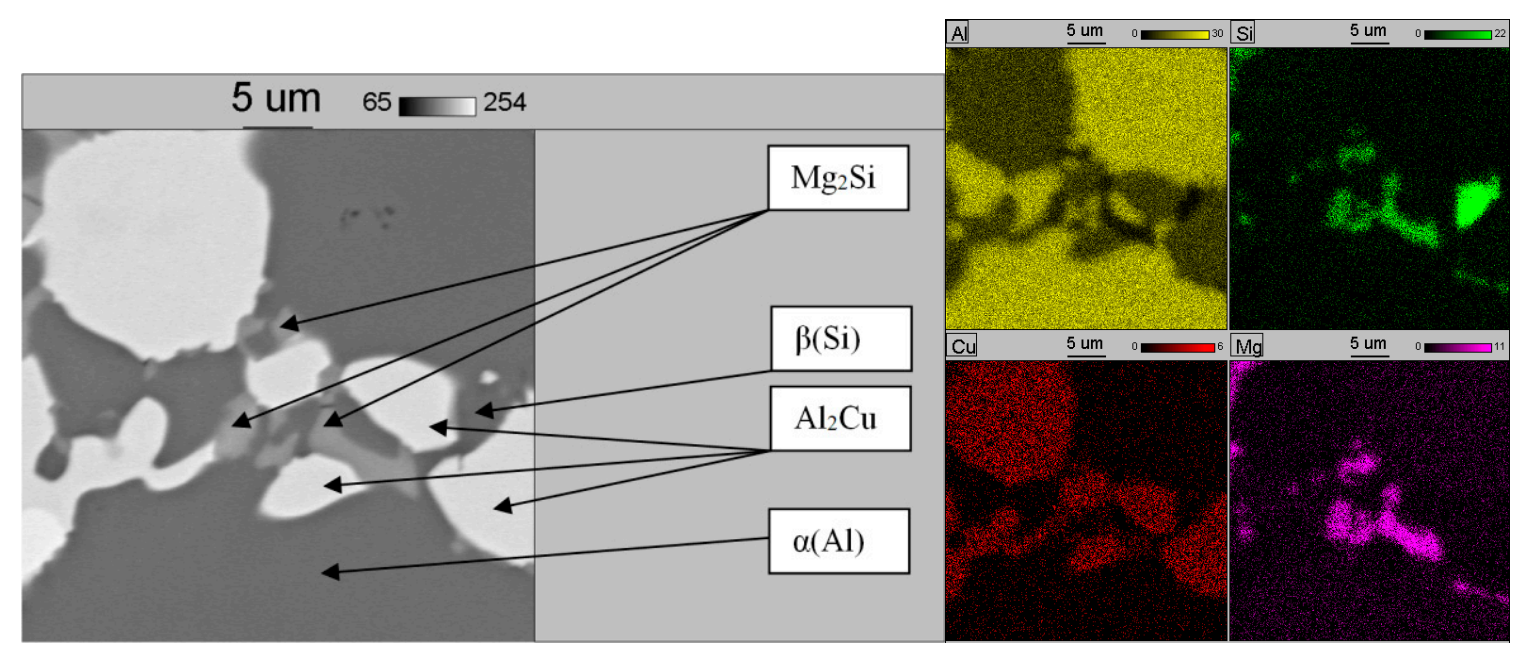

Figure 5. An example of the quaternary eutectic region of EN AC-4600 alloy and a map of $\mathrm{Al}, \mathrm{Si}, \mathrm{Cu}$, and $\mathrm{Mg}$ distribution.

From the presented data, it can be concluded that in this region solid solutions $\alpha(\mathrm{Al})$ and $\beta(\mathrm{Si})$ as well as the intermetallic phases $\mathrm{Al}_{2} \mathrm{Cu}$ and $\mathrm{Mg}_{2} \mathrm{Si}$ occur. Analogous analyzes were carried out in other regions of the material; they showed the presence of intermetallic phases crystallizing in the $\mathrm{Al}-\mathrm{Cu}-\mathrm{Ni}$, Al-Fe-Mn-Si, and Al-Cu-Mg-Si systems within the quaternary eutectic.

Figure 6 shows the microstructure of the HPDC EN AC-46000 base alloy. 


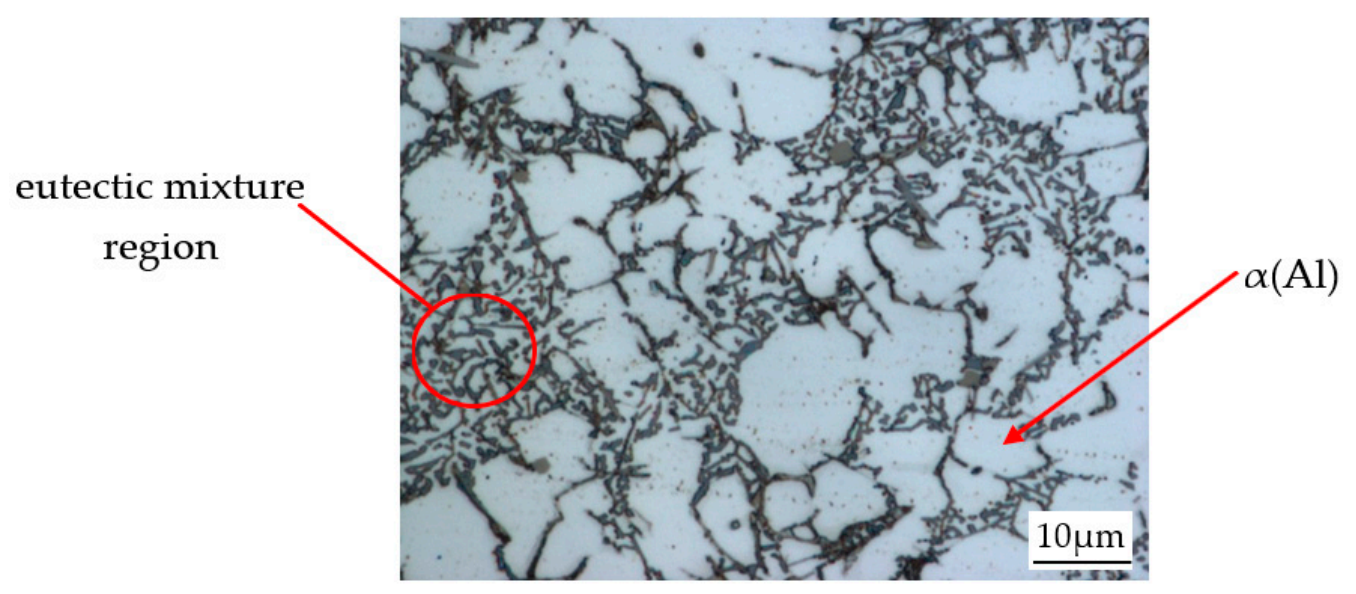

Figure 6. Microstructure of the high-pressure die casting (HPDC) EN AC-46000 base alloy: $\alpha(\mathrm{Al})$, eutectic region.

The microstructure consists of $\alpha(\mathrm{Al})$ solid solution dendrites and eutectic composed of $\alpha(\mathrm{Al})$, $\beta(\mathrm{Si})$ solutions and intermetallic phases. Precipitations of the $\beta(\mathrm{Si})$ phase in eutectic mixture are characterized by lamellar morphology. This microstructure differs from the base alloy from the shell mold mainly in the phases size. This is, of course, due to the much higher heat transfer from the casting to the pressure die casting mold compared to the shell mold. In addition to a significant reduction in the size of the precipitates, intense heat transfer to the pressure die casting mold may result in supersaturation of the $\alpha(\mathrm{Al})$ solid solution with alloying elements. Due to the above, a lower volume fraction of intermetallic phases in the Al-Si alloy can be obtained. High intensity of heat transfer from the casting can also lead to a more compact morphology of intermetallic phases. In the presented microstructure, there are no intermetallic phases with the morphology of "Chinese writing". Diffraction tests showed the presence of intermetallic phases: $\mathrm{Al}_{2} \mathrm{Cu}, \mathrm{Al}_{2} \mathrm{CuMg}$, and other phases that crystallize in the systems: Al-Fe-Si, $\mathrm{Al}-\mathrm{Cu}-\mathrm{Fe}$, and $\mathrm{Mn}-\mathrm{Ni}-\mathrm{Si}$. Due to the very intensive process of solidification in the pressure die casting mold, the chemical composition of the individual phases varies greatly from the equilibrium composition. Figure 7 shows the results of the point analysis of the chemical composition of the selected intermetallic phase in the tested alloy. The results indicate that it may be $\mathrm{Al}_{2} \mathrm{Cu}$ phase with dissolved magnesium and silicon at a concentration of 0.45 and $5.24 \mathrm{wt} \%$, respectively.

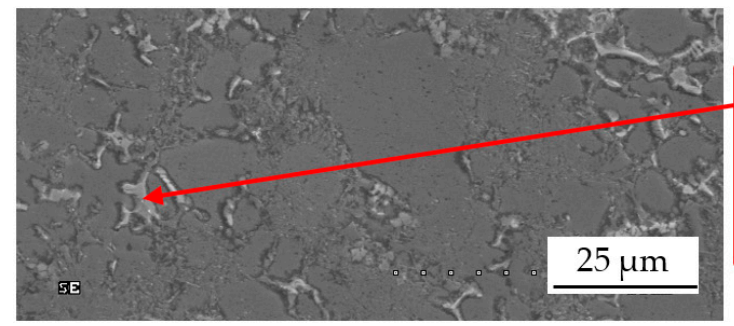

\begin{tabular}{|lccrrc|}
\hline Element & $\begin{array}{c}\text { k-ratio } \\
\text { (calc.) }\end{array}$ & ZAF & Atom \% & $\begin{array}{r}\text { Element } \\
\text { Wt } \%\end{array}$ & $\begin{array}{c}\text { Wt } \% \text { Err. } \\
(1-\text { Sigma })\end{array}$ \\
Mg-K & 0.0025 & 1.786 & 0.66 & 0.45 & $+/-0.10$ \\
Al-K & 0.3494 & 1.498 & 69.15 & 52.35 & $+/-0.37$ \\
Si-K & 0.0295 & 1.778 & 6.65 & 5.24 & $+/-0.22$ \\
Cu-K & 0.3728 & 1.125 & 23.53 & 41.95 & $+/-1.80$ \\
Total & & & 100.00 & 100.00 & \\
\hline
\end{tabular}

Figure 7. Results of the point analysis of the chemical composition of the intermetallic phase in the microstructure of HPDC EN AC-46000 alloy. The arrow indicates the phase under analysis.

\subsection{Al-Si Alloys with High Melting Point Elements from the Shell Mold}

Relatively small amounts of high melting point elements in the alloy from the shell mold do not cause significant changes in the thermal and derivative curves as well as the alloy microstructure. These elements attach mainly to the intermetallic phases in eutectic mixtures. There are no 'new' phases, and no additional thermal effects are recorded in the thermal and derivative curves. For example, Figure 8 shows the region of the ternary eutectic in the alloy with $\sim 0.2 \mathrm{wt} \% \mathrm{~V}$ and $\mathrm{W}$ from the shell sand probe, along with the analysis of the elements' distribution. The presented data shows the presence of 
a solid solution $\alpha(\mathrm{Al})$, silicon plates and the intermetallic phase with increased content of $\mathrm{Al}, \mathrm{Fe}, \mathrm{V}$, $\mathrm{Mn}$, and $\mathrm{W}$ within the ternary eutectic. The last of the phases presented is also characterized by an increased concentration of Si. Diffraction studies did not allow for unambiguous identification of this phase, but due to the elements it contains and the characteristic morphology of the "Chinese writing" type, it was assumed that it is $\mathrm{Al}_{15}(\mathrm{Fe}, \mathrm{Mn}, \mathrm{V}, \mathrm{W})_{3} \mathrm{Si}_{2}$ phase. Fine precipitations of pure lead adhere to this phase. In the analyzed region, there are also places with an increased concentration of copper, magnesium, and aluminum. This suggests that the quaternary eutectic adheres to the analyzed grain of the ternary eutectic.

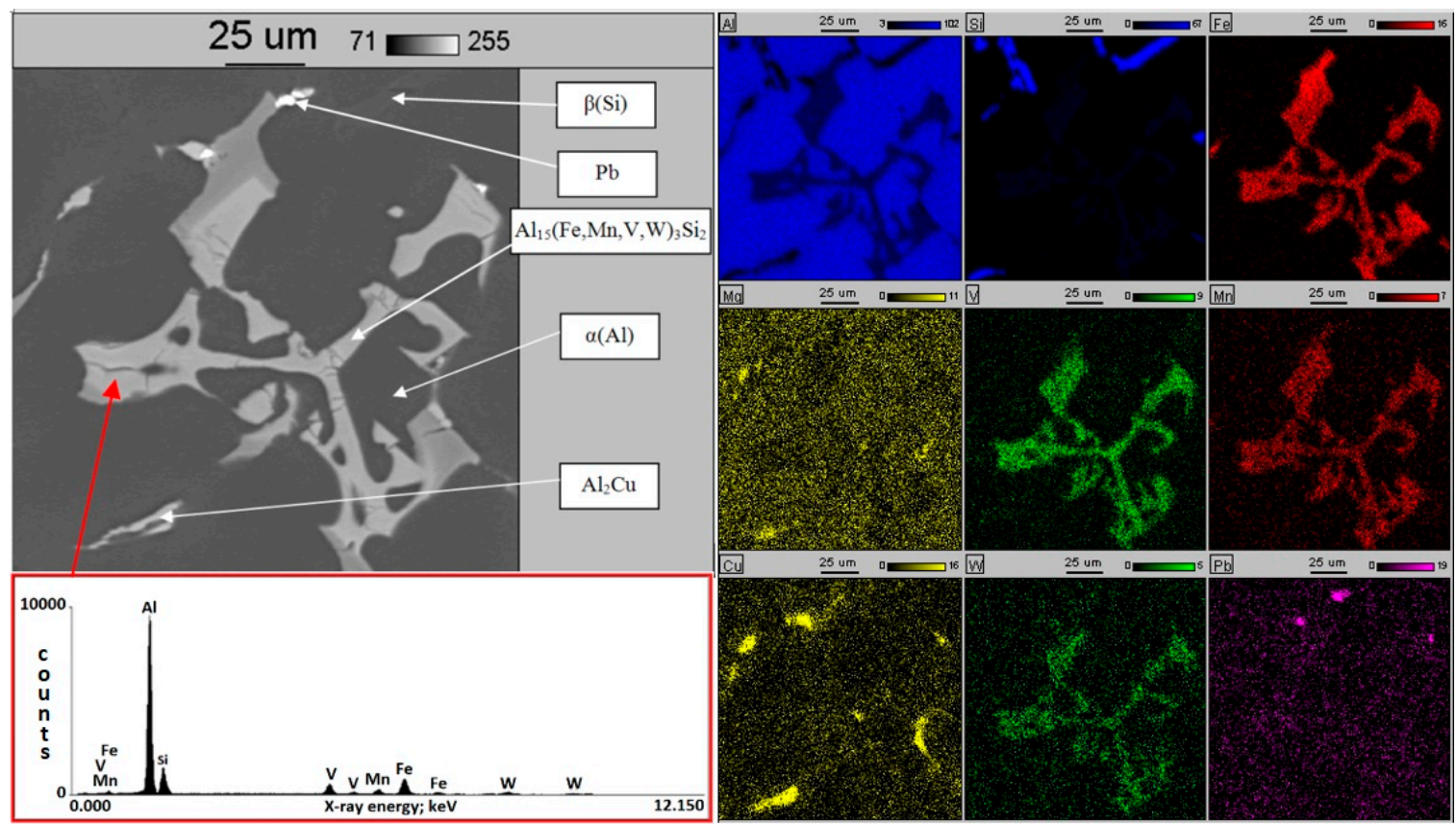

Figure 8. Region of the ternary eutectic in the alloy with $\sim 0.2 \mathrm{wt} \% \mathrm{~V}$ and $\mathrm{W}$ from the shell sand probe and the distribution analysis of elements.

An example of the quaternary eutectic region with the distribution analysis of elements is shown in Figure 9.

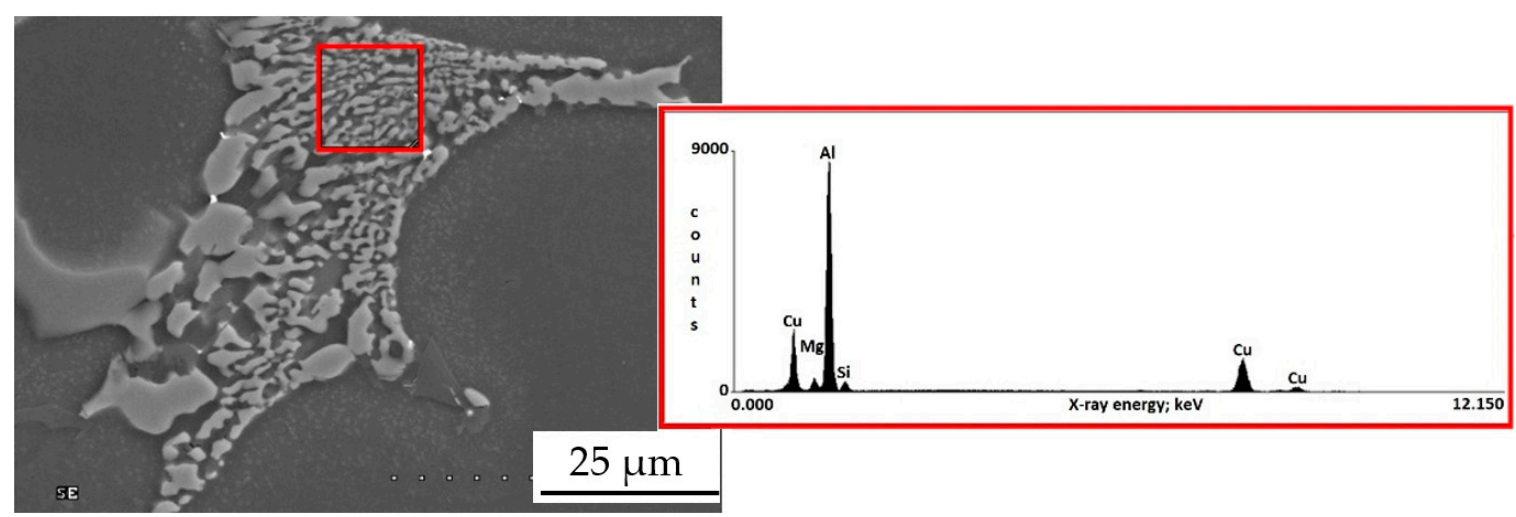

Figure 9. Region of the quaternary eutectic in the alloy with $\sim 0.2 \mathrm{wt} \% \mathrm{~V}$ and $\mathrm{W}$ from the shell sand probe and the distribution analysis of elements.

The increased content of $\mathrm{Al}, \mathrm{Si}, \mathrm{Cu}$, and $\mathrm{Mg}$ in the studied region indicates the possibility of the presence of $\alpha(\mathrm{Al})$ phase, Si crystals, intermetallic phases $\mathrm{Al}_{2} \mathrm{Cu}$ and $\mathrm{Mg}_{2} \mathrm{Si}$ or more complex phases containing the above mentioned elements. In the quaternary eutectic, there may also be fine precipitates 
of the intermetallic phases containing high melting point elements. Analogous analyses of the chemical composition of the phases in the quaternary eutectic of the Al-Si alloy with the high-melting point elements have shown the possibility of the presence of phases that crystallize in the Al-Fe-Si-Mn-M system, where $\mathrm{M}$ is any high melting point element or a combination of such elements.

When a certain limit content of high-melting elements is exceeded, the additional thermal effect is registered in the thermal and derivative curves. This effect is presented, for example, on the curves of Al-Si alloy with $0.2 \mathrm{wt} \% \mathrm{Cr}, \mathrm{Mo}, \mathrm{V}$, and $\mathrm{W}$ each (Figure 1 -red color). It was described as $\mathrm{C}_{\mathrm{s}} \mathrm{A}^{\prime} \mathrm{A}^{\prime \prime}$. The precipitation of the 'new' phase related to the $\mathrm{C}_{\mathrm{s}} \mathrm{A}^{\prime} \mathrm{A}^{\prime \prime}$ effect is shown, for example, in the microstructure of Al-Si alloy containing $0.3 \mathrm{wt} \% \mathrm{Cr}$ (Figure 10). This phase is characterized by a morphology similar to dendritic. The point analysis of the chemical composition in the 'new' phase precipitation presented in Figure 11 indicates that it is probably $\mathrm{Al}_{15}(\mathrm{Fe}, \mathrm{Mn}, \mathrm{Cr})_{3} \mathrm{Si}_{2}$ phase with a small amount of $\mathrm{Cu}$ and $\mathrm{Ni}$ dissolved. The thermal effect $\mathrm{C}_{\mathrm{S}} \mathrm{A}^{\prime} \mathrm{A}^{\prime \prime}$ associated with the $\mathrm{Al}_{15}(\mathrm{Fe}, \mathrm{Mn}, \mathrm{Cr})_{3} \mathrm{Si}_{2}$ phase occurs before the $\mathrm{A}^{\prime \prime} \mathrm{AB}$ effect, which is caused by the crystallization of $\alpha(\mathrm{Al})$ solid solution, so with a sufficiently high chromium content this phase may crystallize primarily. Analogous phases (and related $\mathrm{C}_{\mathrm{s}} \mathrm{A}^{\prime} \mathrm{A}^{\prime \prime}$ effects on thermal and derivative curves) also occur in alloy containing high melting point elements other than $\mathrm{Cr}$, or any combinations of them, however, with a sufficiently high content of high melting point elements. For simplicity, this phase is designated as $\mathrm{Al}_{15}(\mathrm{Fe}, \mathrm{Mn}, \mathrm{M})_{3} \mathrm{Si}_{2}$, where $\mathrm{M}$ is any high melting point element or a combination of them.

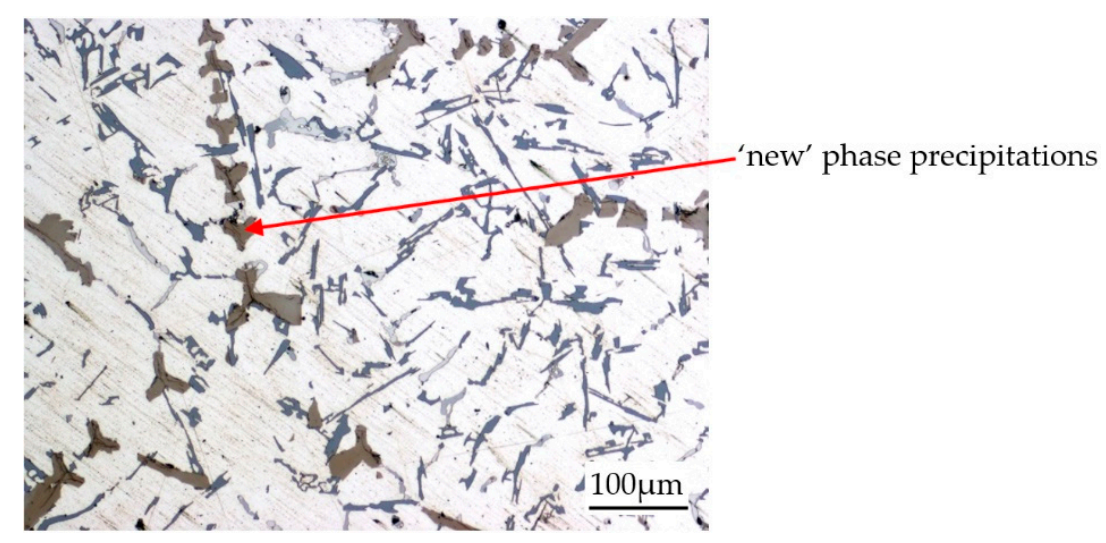

Figure 10. Microstructure of Al-Si alloy with approximately $0.3 \mathrm{wt} \% \mathrm{Cr}$ in the shell sand probe: $\mathrm{Al}_{15}(\mathrm{Fe}, \mathrm{Mn}, \mathrm{Cr})_{3} \mathrm{Si}_{2}, \alpha(\mathrm{Al}), \alpha+\beta, \alpha+\mathrm{Al}_{2} \mathrm{Cu}+\mathrm{AlSiCuFeMgMnNiCr}+\beta$.

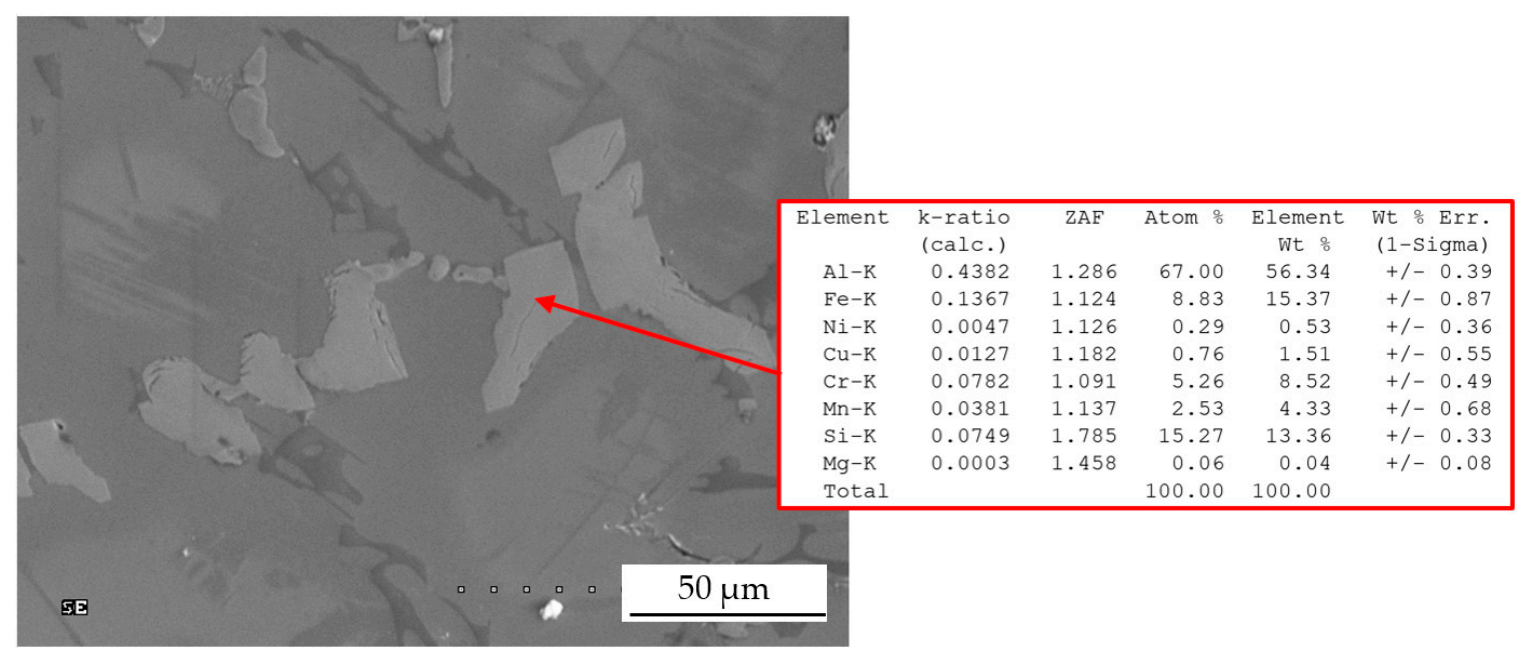

Figure 11. Point analysis of the chemical composition of the primary intermetallic phase in the microstructure of the tested alloy from the shell sand probe. 
The minimum content of high melting point elements at which the primary $\mathrm{Al}_{15}(\mathrm{Fe}, \mathrm{Mn}, \mathrm{M})_{3} \mathrm{Si}_{2}$ intermetallic phases ware observed is shown in Table 3.

Table 3. Minimum content of high melting point elements, at which the primary intermetallic $\mathrm{Al}_{15}(\mathrm{Fe}, \mathrm{Mn}, \mathrm{M})_{3} \mathrm{Si}_{2}$ phases were observed.

\begin{tabular}{|c|c|c|}
\hline \multicolumn{2}{|c|}{ Combinations of High Melting Point Elements } & $\begin{array}{c}\text { Content of High Melting Point Elements, at which the } \\
\text { Primary Crystallization of the } \mathrm{Al}_{15}(\mathrm{Fe}, \mathrm{Mn}, \mathrm{M})_{3} \mathrm{Si}_{2} \\
\text { Phase Was Observed; wt } \%\end{array}$ \\
\hline \multirow{4}{*}{ Single elements } & $\mathrm{Cr}$ & 0.2 \\
\hline & Mo & 0.5 \\
\hline & $\mathrm{V}$ & $-*$ \\
\hline & W & 0.5 \\
\hline \multirow{6}{*}{ Double combinations } & $\mathrm{Cr}, \mathrm{Mo}$ & 0.1 each \\
\hline & $\mathrm{Cr}, \mathrm{V}$ & 0.1 each \\
\hline & $\mathrm{Cr}, \mathrm{W}$ & 0.1 each \\
\hline & Mo, V & 0.4 each \\
\hline & Mo, W & 0.3 each \\
\hline & $\mathrm{V}, \mathrm{W}$ & $-*$ \\
\hline \multirow{4}{*}{ Triple combinations } & $\mathrm{Cr}, \mathrm{Mo}, \mathrm{V}$ & 0.25 each \\
\hline & $\mathrm{Cr}, \mathrm{Mo}, \mathrm{W}$ & 0.25 each \\
\hline & $\mathrm{Cr}, \mathrm{V}, \mathrm{W}$ & 0.20 each \\
\hline & Mo, V, W & 0.25 each \\
\hline Simultaneously & $\mathrm{Cr}, \mathrm{Mo}, \mathrm{V}, \mathrm{W}$ & 0.10 each \\
\hline
\end{tabular}

Note: * probably the primary crystallization of the $\mathrm{Al}_{15}(\mathrm{Fe}, \mathrm{Mn}, \mathrm{M})_{3} \mathrm{Si}_{2}$ phase occurs out of range of the tested content of high melting point elements.

In the case of alloys in which $\mathrm{Al}_{15}(\mathrm{Fe}, \mathrm{Mn}, \mathrm{M})_{3} \mathrm{Si}_{2}$ primary phase crystallizes, it was observed that it absorbs so many $\mathrm{Fe}, \mathrm{Mn}$, and high melting point elements atoms that within the thermal effect BEH (Figure 1), the ternary eutectic does not crystallize. Instead, the classical $\alpha(\mathrm{Al})+\beta(\mathrm{Si})$ binary eutectic mixture crystallizes, which does not contain the $\mathrm{Al}_{15}(\mathrm{Fe}, \mathrm{Mn}, \mathrm{M})_{3} \mathrm{Si}_{2}$ phase with the morphology of "Chinese writing". On the other hand, the quaternary eutectic (HKL effect-Figure 1) is analogous for all tested alloys containing high melting point elements. It consists of $\alpha(\mathrm{Al})$ and $\beta(\mathrm{Si})$ solid solutions, the $\mathrm{Al}_{2} \mathrm{Cu}$ phase and the next phase, the composition of which depends on the residual liquid which is differentiated due to microsegregation. Most often, this is $\mathrm{Mg}_{2} \mathrm{Si}$ or $\mathrm{Al}_{15}(\mathrm{Fe}, \mathrm{Mn}, \mathrm{M})_{3} \mathrm{Si}_{2}$ phase. An example of the quaternary eutectic region in Al-Si alloy containing $0.4 \mathrm{wt} \% \mathrm{Cr}$ and the map of $\mathrm{Al}, \mathrm{Si}, \mathrm{Fe}, \mathrm{Cr}, \mathrm{Mn}$, and $\mathrm{Cu}$ distribution are shown in Figure 12. The presented data indicate that in this region there are $\alpha(\mathrm{Al}), \beta(\mathrm{Si}), \mathrm{Al}_{2} \mathrm{Cu}$, and $\mathrm{Al}_{15}(\mathrm{Fe}, \mathrm{Mn}, \mathrm{Cr})_{3} \mathrm{Si}_{2}$ phases.
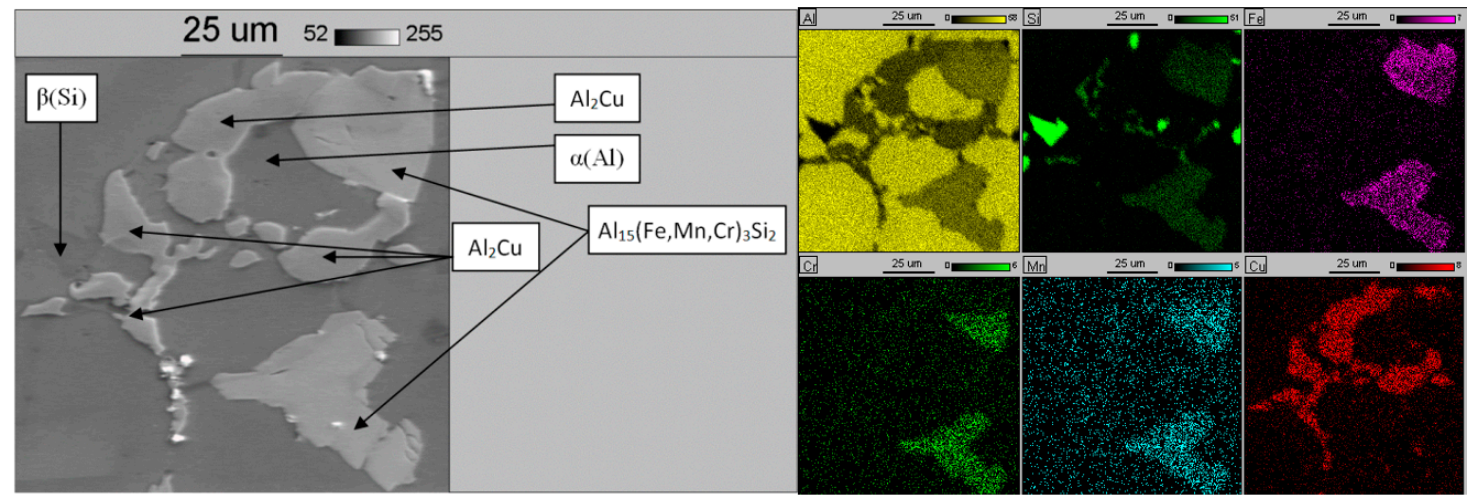

Figure 12. An example of the quaternary eutectic region of Al-Si alloy containing $0.4 \mathrm{wt} \%$ and the map of $\mathrm{Al}, \mathrm{Si}, \mathrm{Fe}, \mathrm{Cr}, \mathrm{Mn}$, and $\mathrm{Cu}$ distribution. 


\subsection{High Pressure Die Casting (HPDC) Al-Si Alloys with High Melting Point Elements}

In the case of HPDC alloy, the addition of relatively small amounts of high melting point elements does not cause significant changes in terms of the phases in the microstructure. High melting point elements are mainly built into the intermetallic phases in the eutectic mixture or, due to the high intensity of heat transfer from the casting to the pressure die casting mold, they supersaturate $\alpha(\mathrm{Al})$ solid solution. The average solidification rate of HPDC alloy containing high-melting point elements, calculated on the basis of the secondary dendrite arm spacing (SDAS), was $56.6^{\circ} \mathrm{C} / \mathrm{s}$. Similarly to the case of alloy from the shell mold, a certain limit content of high-melting elements also causes the formation of 'new' intermetallic phases in the microstructure of the HPDC alloy. Figure 13 shows an example of the microstructure of a HPDC alloy containing V and W.

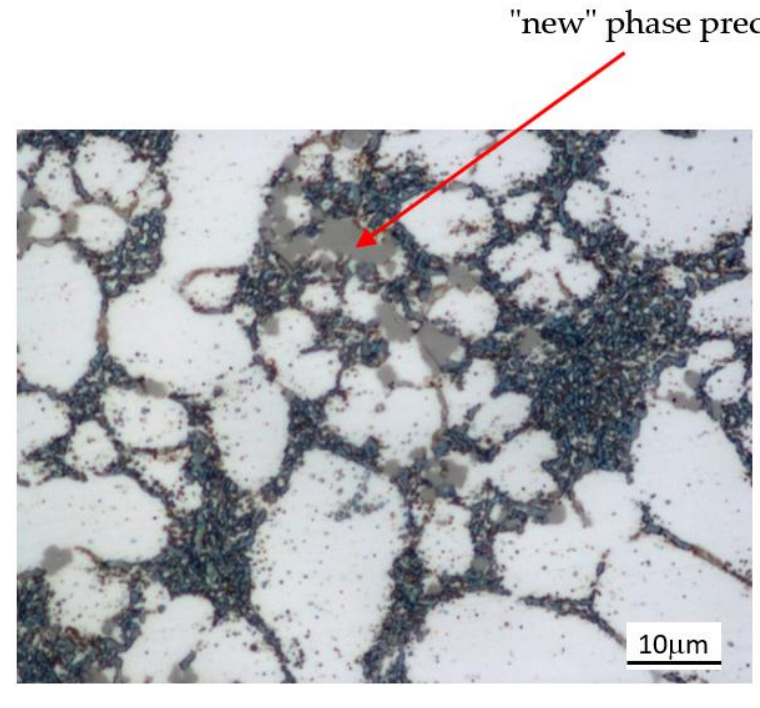

(a)

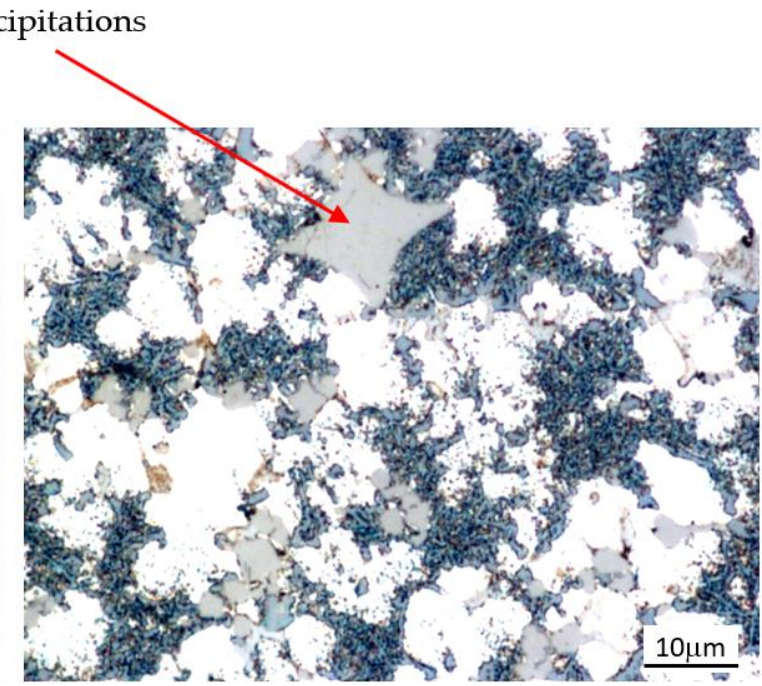

(b)

Figure 13. Microstructure of the HPDC Al-Si alloy with the addition of $\mathrm{V}$ and $\mathrm{W}$ in an amount of approximately (a) $0.2 \mathrm{wt} \%$, (b) $0.3 \mathrm{wt} \%$. The microstructure: 'new' intermetallic phase, $\alpha(\mathrm{Al})$, eutectic mixture.

In Al-Si alloy with the addition of about $0.2 \mathrm{wt} \% \mathrm{~V}$ and $\mathrm{W}$, a 'new' intermetallic phase was formed; it is characterized by a compact-block morphology, while increasing the content of $\mathrm{V}$ and $\mathrm{W}$ to $0.3 \mathrm{wt} \%$ also causes the crystallization of this phase, but with a morphology similar to a four-pointed star or polygon. This phase penetrates both the $\alpha(\mathrm{Al})$ dendrites as well as eutectic regions. This allows the conclusion that these phases contain high melting point elements and crystallize directly from the liquid at a temperature higher than the other phases. The content of high melting point elements, at which 'new' primary phases were observed in the microstructure of HPDC alloy is shown in Table 4 .

Figure 14 shows an example of the region in the microstructure of HPDC Al-Si alloy containing $0.5 \mathrm{wt} \% \mathrm{Cr}$ with a 'new' phase and the map of $\mathrm{Si}, \mathrm{Fe}, \mathrm{Cr}, \mathrm{Mn}$, and $\mathrm{Cu}$ distribution. 
Table 4. Minimum content of high melting point elements, at which the primary 'new' intermetallic phases were observed.

\begin{tabular}{|c|c|c|}
\hline \multicolumn{2}{|c|}{ Combinations of High Melting Point Elements } & $\begin{array}{l}\text { The Content of High Melting Point Elements, } \\
\text { at which the Primary } \mathrm{Al}_{15}(\mathrm{Fe}, \mathrm{Mn}, \mathrm{M})_{3} \mathrm{Si}_{2} \text { Phase Was } \\
\text { Observed; wt \% }\end{array}$ \\
\hline \multirow{4}{*}{ Single elements } & $\mathrm{Cr}$ & 0.2 \\
\hline & Mo & 0.2 \\
\hline & $\mathrm{V}$ & 0.2 \\
\hline & $\mathrm{W}$ & 0.2 \\
\hline \multirow{6}{*}{ Double combinations } & $\mathrm{Cr}, \mathrm{Mo}$ & 0.2 each \\
\hline & $\mathrm{Cr}, \mathrm{V}$ & 0.2 each \\
\hline & $\mathrm{Cr}, \mathrm{W}$ & 0.2 each \\
\hline & Mo, V & 0.2 each \\
\hline & Mo, W & 0.2 each \\
\hline & $\mathrm{V}, \mathrm{W}$ & 0.2 each \\
\hline \multirow{4}{*}{ Triple combinations } & $\mathrm{Cr}, \mathrm{Mo}, \mathrm{V}$ & 0.2 each \\
\hline & $\mathrm{Cr}, \mathrm{Mo}, \mathrm{W}$ & 0.2 each \\
\hline & $\mathrm{Cr}, \mathrm{V}, \mathrm{W}$ & 0.2 each \\
\hline & Mo, V, W & 0.2 each \\
\hline Simultaneously & $\mathrm{Cr}, \mathrm{Mo}, \mathrm{V}, \mathrm{W}$ & 0.05 each \\
\hline
\end{tabular}

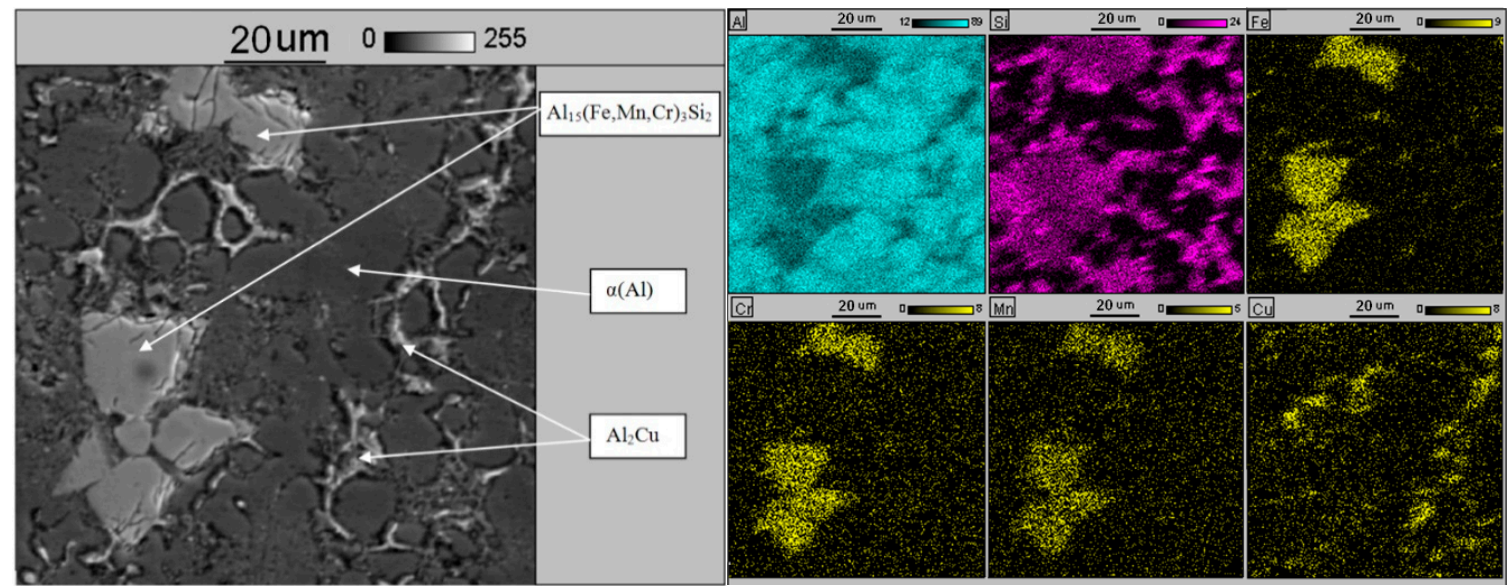

Figure 14. An example of the region in the microstructure of Al-Si alloy containing $0.5 \mathrm{wt} \% \mathrm{Cr}$ with a 'new' phase and the map of $\mathrm{Si}, \mathrm{Fe}, \mathrm{Cr}, \mathrm{Mn}$, and $\mathrm{Cu}$ distribution.

The increased concentration of $\mathrm{Al}, \mathrm{Si}, \mathrm{Fe}, \mathrm{Cr}$, and $\mathrm{Mn}$ in the 'new' phase indicates that it is probably $\mathrm{Al}_{15}(\mathrm{Fe}, \mathrm{Mn}, \mathrm{Cr})_{3} \mathrm{Si}_{2}$ intermetallic phase. The high concentration of aluminum and simultaneously aluminum and copper in the region surrounding the analyzed $\mathrm{Al}_{15}(\mathrm{Fe}, \mathrm{Mn}, \mathrm{Cr})_{3} \mathrm{Si}_{2}$ phase indicates the presence of $\alpha$ phase dendrites and eutectic mixture containing $\mathrm{Al}_{2} \mathrm{Cu}$ phases. The 'new' iron-rich phase can contain all high melting point elements tested. This is indicated by the research on the chemical composition of this phases in Al-Si alloy containing about $0.25 \mathrm{wt} \%$ of each high melting point elements tested (simultaneously added). The chemical composition was investigated on ten randomly selected precipitates of 'new' intermetallic phases. Figure 15 shows an example of the intermetallic phase tested in this alloy while in Table 5 the chemical composition of the 10 randomly selected phases is presented. 


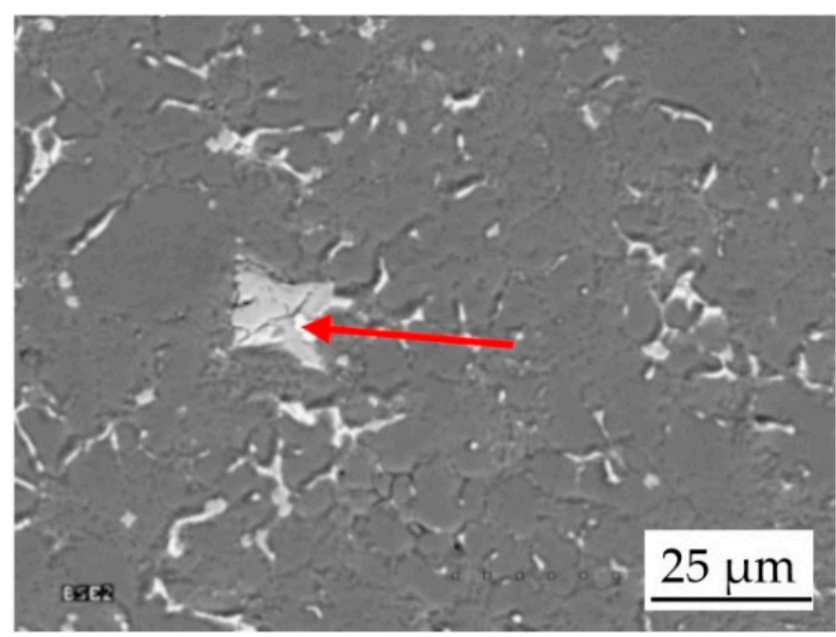

Figure 15. Microstructure of the HPDC Al-Si alloy containing approximately $0.25 \mathrm{wt} \% \mathrm{Cr}, \mathrm{Mo}, \mathrm{V}$, and $\mathrm{W}$ each with a marked example of the tested phase.

Table 5. The chemical composition of ten randomly selected phases.

\begin{tabular}{ccccccccc}
\hline \multirow{2}{*}{ Phase No. } & \multicolumn{7}{c}{ Concentration, wt \% } \\
\cline { 2 - 9 } & Al & Si & Fe & Mn & Cr & Mo & V & W \\
\hline 1 & 56.04 & 9.50 & 15.56 & 4.25 & 6.40 & 5.10 & 2.64 & 0.52 \\
\hline 2 & 56.28 & 9.28 & 19.73 & 4.82 & 6.56 & 3.30 & 2.74 & 0.29 \\
\hline 3 & 56.47 & 8.86 & 16.27 & 5.38 & 5.29 & 3.80 & 3.08 & 0.86 \\
\hline 4 & 58.81 & 12.33 & 15.03 & 4.69 & 4.20 & 2.57 & 2.12 & 0.25 \\
\hline 5 & 56.86 & 9.10 & 15.78 & 4.17 & 6.44 & 3.72 & 2.96 & 0.99 \\
\hline 6 & 56.78 & 9.05 & 15.59 & 4.15 & 6.03 & 4.17 & 2.30 & 1.93 \\
\hline 7 & 69.73 & 6.40 & 9.57 & 3.33 & 3.41 & 2.58 & 1.27 & 3.71 \\
\hline 8 & 57.00 & 8.91 & 16.31 & 5.66 & 5.23 & 3.76 & 2.83 & 0.40 \\
\hline 9 & 59.75 & 9.10 & 15.62 & 4.91 & 5.31 & 2.78 & 2.12 & 0.40 \\
\hline 10 & 56.46 & 9.00 & 17.12 & 4.08 & 6.10 & 3.70 & 2.55 & 0.99 \\
\hline Average & 58.42 & 9.15 & 15.66 & 4.54 & 5.50 & 3.55 & 2.46 & 1.03 \\
\hline
\end{tabular}

Each tested precipitation consists of $\mathrm{Al}, \mathrm{Si}, \mathrm{Fe}, \mathrm{Mn}$ as well as $\mathrm{Cr}, \mathrm{Mo}, \mathrm{V}$, and $\mathrm{W}$. The average concentration of elements indicates that it is a phase similar to $\mathrm{Al}_{15}(\mathrm{Fe}, \mathrm{Mn})_{3} \mathrm{Si}_{2}$, in which in which $\mathrm{Fe}$ and $\mathrm{Mn}$ atoms were replaced by $\mathrm{Cr}, \mathrm{Mo}, \mathrm{V}$, and $\mathrm{W}$. The previously introduced designation $\mathrm{Al}_{15}(\mathrm{Fe}, \mathrm{Mn}, \mathrm{M})_{3} \mathrm{Si}_{2}$ was used to describe this phase. The average concentration of high melting point elements in this phase indicates that it adopts chromium atoms to the greatest extent, molybdenum and vanadium to a lesser extent, and tungsten to the smallest extent. Both in the case of HPDC alloy as well as from the shell mold, the amount and size of the primary $\mathrm{Al}_{15}(\mathrm{Fe}, \mathrm{Mn}, \mathrm{M})_{3} \mathrm{Si}_{2}$ phase increases, which results in an increase in the area fraction. Figure 16 shows, for example, changes in the area fraction of the primary $\mathrm{Al}_{15}(\mathrm{Fe}, \mathrm{Mn}, \mathrm{M})_{3} \mathrm{Si}_{2}$ phase in a $\mathrm{Al}-\mathrm{Si}$ alloy containing vanadium (a) and simultaneously $\mathrm{Cr}, \mathrm{Mo}$, $\mathrm{V}$, and $\mathrm{W}(\mathrm{b})$ occurring with an increase in their concentration. 


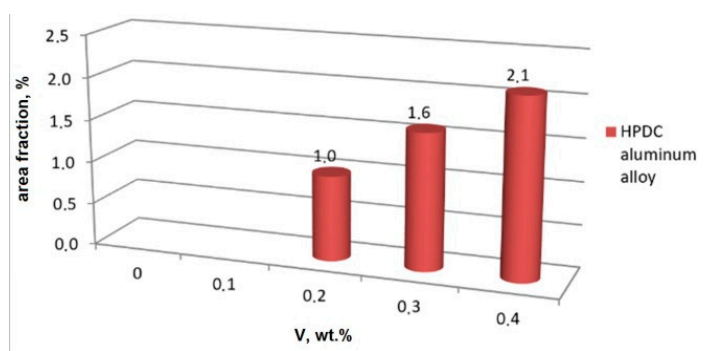

(a)

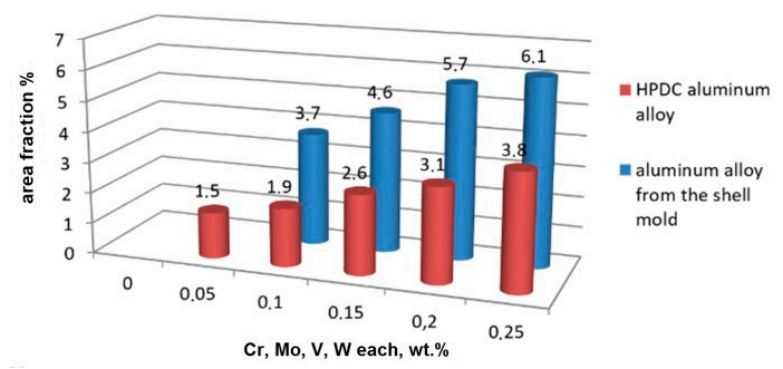

(b)

Figure 16. Changes in the area fraction of the primary $\mathrm{Al}_{15}(\mathrm{Fe}, \mathrm{Mn}, \mathrm{M})_{3} \mathrm{Si}_{2}$ phase in a $\mathrm{Al}-\mathrm{Si}$ alloy containing vanadium (a) and simultaneously $\mathrm{Cr}, \mathrm{Mo}, \mathrm{V}$, and $\mathrm{W}(\mathbf{b})$.

The presented data show that from the moment of the appearance of the primary $\mathrm{Al}_{15}(\mathrm{Fe}, \mathrm{Mn}, \mathrm{M})_{3} \mathrm{Si}_{2}$ phase, further increasing the content of high melting point elements causes an increase in its area fraction. The lack of data on the area fraction of this phase in the vanadium-containing alloy from the shell mold (Figure 16a) results from the fact that this phase does not occur in the alloy microstructure in the studied range of $\mathrm{V}$ content (Table 3). The data presented in Figure 16b also shows a greater area fraction of the $\mathrm{Al}_{15}(\mathrm{Fe}, \mathrm{Mn}, \mathrm{M})_{3} \mathrm{Si}_{2}$ phase in the alloy from the shell mold compared to the HPDC alloy.

This section may be divided by subheadings. It should provide a concise and precise description of the experimental results, their interpretation as well as the experimental conclusions that can be drawn.

\section{Discussion}

The results presented in the paper showed a three-stage solidification process of AlSi9Cu3(Fe) base alloy in a shell mold. The dendrites of $\alpha(\mathrm{Al})$ solid solution are the first to crystallize at the highest temperature. Then the ternary and quaternary eutectic mixtures crystallize. In the ternary eutectic mixture, apart from $\alpha(\mathrm{Al})$ and $\beta(\mathrm{Si})$ solid solutions, there is an intermetallic $\mathrm{Al}_{15}(\mathrm{Fe}, \mathrm{Mn})_{3} \mathrm{Si}_{2}$ phase with the morphology of "Chinese writing". The quaternary eutectic mixture formed from the remains of the liquid consists of the $\alpha(\mathrm{Al})$ and $\beta(\mathrm{Si})$ solutions, the $\mathrm{Al}_{2} \mathrm{Cu}$ intermetallic phase as well as another intermetallic phase. The chemical composition of the latter phase depends on the different, as a result of microsegregation, the content of elements in different areas of the liquid metal in the final phase of the solidification process. Most often it is $\mathrm{Mg}_{2} \mathrm{Si}$ phase, but phases from $\mathrm{Al}-\mathrm{Cu}-\mathrm{Ni}, \mathrm{Al}-\mathrm{Fe}-\mathrm{Mn}-\mathrm{Si}$, and $\mathrm{Al}-\mathrm{Cu}-\mathrm{Mg}-\mathrm{Si}$ systems have also been found in the quaternary eutectic mixture. A relatively small amount of high melting point elements does not create 'new' phases in the microstructure. These elements attach mainly to iron-rich intermetallic phases which are described as $\mathrm{Al}_{15}(\mathrm{Fe}, \mathrm{Mn}, \mathrm{M})_{3} \mathrm{Si}_{2}$. Exceeding a certain critical content of high melting point elements generally causes crystallization of the $\mathrm{Al}_{15}(\mathrm{Fe}, \mathrm{Mn}, \mathrm{M})_{3} \mathrm{Si}_{2}$ phase at a temperature higher than the crystallization temperature of $\alpha(\mathrm{Al})$ dendrites. This process was not observed in alloys containing vanadium and a combination of vanadium and tungsten in the studied range. The amount of this phase in the microstructure increases with the increase in the content of high melting point elements. The primary crystallization of this phase causes the depletion of the remaining liquid in high melting point elements, which causes the crystallization of the lamellar eutectic $\alpha(\mathrm{Al})+\beta(\mathrm{Si})$ instead of the ternary eutectic mixture.

The microstructure of AlSi9Cu3(Fe) HPDC alloy without high melting point elements consists of dendrites of $\alpha(\mathrm{Al})$ phase and the eutectic mixture. The eutectic mixture consists of $\alpha(\mathrm{Al})$ and $\beta(\mathrm{Si})$ solid solutions and relatively fine precipitations of intermetallic phases. These are mainly copper and magnesium phases, and to a lesser extent iron, manganese, and nickel phases. The intensive heat transfer during HPDC process results in a much finer microstructure compared to shell mold castings. The size reduction in $\alpha(\mathrm{Al})$ dendrites and the eutectic mixture phases is observed. The addition of a certain critical content of high melting point elements causes, similarly to the case of alloy from the 
shell mold, the primary crystallization of the $\mathrm{Al}_{15}(\mathrm{Fe}, \mathrm{Mn}, \mathrm{M})_{3} \mathrm{Si}_{2}$ intermetallic phase. The content of the above-mentioned elements affects both the amount of the primary phase as well as the morphology of its precipitations. As the content of high melting point elements increases, the amount of this phase increases too, and its morphology changes from a compact block to a polygon or star-like.

From the point of view of the possibility of $\alpha(\mathrm{Al})$ phase supersaturation with high melting point elements, the most important factor related to the formation of the microstructure seems to be the amount of the primary $\mathrm{Al}_{15}(\mathrm{Fe}, \mathrm{Mn}, \mathrm{M})_{3} \mathrm{Si}_{2}$ phase. The addition of high melting point elements within the content that does not cause the formation of the primary phase results in an increase in the concentration of these elements before $\alpha(\mathrm{Al})$ dendrite crystallization front. On the other hand, the $\mathrm{Al}_{15}(\mathrm{Fe}, \mathrm{Mn}, \mathrm{M})_{3} \mathrm{Si}_{2}$ phase, which crystallizes at a temperature higher than that of $\alpha(\mathrm{Al})$ dendrites, absorbs a significant amount of high melting point elements and reduces their concentration before the $\alpha(\mathrm{Al})$ phase crystallization front. Due to the above, the greatest possibility of effective supersaturation of $\alpha(\mathrm{Al})$ dendrites with high-melting-point elements is created by their possibly high content in the alloy; which does not, however, cause crystallization of the primary $\mathrm{Al}_{15}(\mathrm{Fe}, \mathrm{Mn}, \mathrm{M})_{3} \mathrm{Si}_{2}$ phase. As the HPDC technology is characterized by a relatively high heat transfer rate from the casting, which favors $\alpha(\mathrm{Al})$ phase supersaturation, it should be considered a great potential for the production of hypoeutectic aluminum alloys with $\mathrm{Cr}, \mathrm{Mo}, \mathrm{V}$, and $\mathrm{W}$.

\section{Conclusions}

The research presented in the paper shows the following conclusions:

1. The addition of a small amount of high-melting point elements to the alloy causes their attachment to the constituent phases of the base alloy.

2. Exceeding a certain limit content of high melting point elements causes the crystallization of $\mathrm{Al}_{15}(\mathrm{FeMnM})_{3} \mathrm{Si}_{2}$ phase at a temperature higher than the crystallization temperature of the primary $\alpha(\mathrm{Al})$ phase. Further increase in the content of high-melting-point elements causes an increase in the area fraction of the $\mathrm{Al}_{15}\left(\mathrm{FeMnM}_{3} \mathrm{Si}_{2}\right.$ phase in the alloy.

3. High-melting-point elements in the range of content that does not cause formation of the primary $\mathrm{Al}_{15}(\mathrm{FeMnM})_{3} \mathrm{Si}_{2}$ phase result in an increase in their concentration before the $\alpha(\mathrm{Al})$ dendrite crystallization front.

4. Primary crystallization of $\mathrm{Al}_{15}(\mathrm{FeMnM})_{3} \mathrm{Si}_{2}$ at a temperature higher than the crystallization temperature of $\alpha(\mathrm{Al})$ dendrites, absorbs a significant amount of high melting point elements, thus reducing their concentration in front of $\alpha(\mathrm{Al})$ dendrite crystallization front.

5. The greatest possibility of effective supersaturation of $\alpha(\mathrm{Al})$ dendrites with high-melting-point elements is created by their possibly high content in the alloy, which does not, however, cause the primary crystallization of the $\mathrm{Al}_{15}\left(\mathrm{FeMnM}_{3} \mathrm{Si}_{2}\right.$ phase.

Author Contributions: Conceptualization, validation, formal analysis, writing-review and editing, T.S. and G.G.; methodology and writing —original draft preparation, T.S.; software, M.G. and L.K.; investigation, T.S., G.G, L.K., and M.G.; project administration and funding acquisition, T.P. All authors have read and agreed to the published version of the manuscript.

Funding: This research received no external funding.

Conflicts of Interest: The authors declare no conflict of interest.

\section{References}

1. Kahler, G.A.; Fisher, F.M.; Sass, R.L. The chemical composition and mechanical properties of the hinge ligament in bivalve molluscs. Biol. Bull. 1976, 151, 161-181. [CrossRef] [PubMed]

2. Taylor, J.A. Iron-Containing Intermetallic Phases in Al-Si Based Casting. In Procedia Materials Science, Proceeding of the 11th International Congress on Metallurgy \& Materials SAM/CONAMET, Rosario, Argentina, 18-21 October 2011; pp. 19-33. Available online: https://www.sciencedirect.com/science/article/pii/S2211812812000053 (accessed on 22 September 2020). 
3. Szymczak, T.; Gumienny, G.; Kurowska, B.; Tadeusz, P. Hypoeutectic Al-Si Alloy doped with Chromium, Tungsten and Molybdenum designated for pressure die casting. Arch. Met. Mater. 2017, 62, 1629-1635. [CrossRef]

4. Dinnis, C.M.; Taylor, J.A.; Dahle, A.K. Porosity formation and eutectic growth in Al-Si-Cu-Mg alloys containing Iron and Manganese. In Proceedings of the 9th International Conference on Aluminium Alloys (ICAA9), Brisbane, Australia, 2-5 August 2004; pp. 1016-1021.

5. Timelli, G.; Bonollo, F. The influence of $\mathrm{Cr}$ content on the microstructure and mechanical properties of $\mathrm{AlSi}_{9} \mathrm{Cu}_{3}(\mathrm{Fe})$ die-casting alloys. Mater. Sci. Eng. A 2010, 528, 273-282. [CrossRef]

6. Outmani, I.; Fouilland-Paille, L.; Isselin, J.; El Mansori, M. Effect of Si, Cu and processing parameters on Al-Si-Cu HPDC castings. J. Mater. Process. Technol. 2017, 249, 559-569. [CrossRef]

7. Dos Santos, S.L.; Antunes, R.A.; Santos, S.F. Influence of injection temperature and pressure on the microstructure, mechanical and corrosion properties of a AlSiCu alloy processed by HPDC. Mater. Des. 2015, 88, 1071-1081. [CrossRef]

8. Makhlouf, M.M.; Apelian, D. Casting Characteristics of Aluminum Die Casting Alloys; Advanced Casting Research Center Worcester Polytechnic Institute: Worcester, MA, USA, 2002.

9. Han, Q.; Viswanathan, S. Analysis of the mechanism of die soldering in Aluminum die casting. Met. Mater. Trans. A 2003, 34, 139-146. [CrossRef]

10. Farkoosh, A.R.; Chen, X.G.; Pekguleryuz, M. Dispersoid strengthening of a high temperature Al-Si-Cu-Mg alloy via Mo addition. Mater. Sci. Eng. A 2015, 620, 181-189. [CrossRef]

11. Li, Y.; Yang, Y.; Wu, Y.; Wei, Z.; Liu, X. Supportive strengthening role of Cr-rich phase on Al-Si multicomponent piston alloy at elevated temperature. Mater. Sci. Eng. A 2011, 528, 4427-4430. [CrossRef]

12. Kim, H.Y.; Han, S.W.; Lee, H.M. The influence of Mn and $\mathrm{Cr}$ on the tensile properties of A356-0.20Fe alloy. Mater. Lett. 2006, 60, 1880-1883. [CrossRef]

13. Elhadari, H.; Patel, H.; Chen, D.; Kasprzak, W. Tensile and fatigue properties of a cast aluminum alloy with Ti, Zr and V additions. Mater. Sci. Eng. A 2011, 528, 8128-8138. [CrossRef]

14. Mbuya, T.O.; Odera, B.O.; Ng'Ang'A, S.P. Influence of iron on castability and properties of aluminium silicon alloys: Literature review. Int. J. Cast Met. Res. 2003, 16, 451-465. [CrossRef]

15. Lin, B.; Li, H.; Xu, R.; Xiao, H.; Zhang, W.; Li, S. Effects of Vanadium on Modification of Iron-Rich Intermetallics and Mechanical Properties in A356 Cast Alloys with 1.5 wt.\% Fe. J. Mater. Eng. Perform. 2018, 28, 475-484. [CrossRef]

16. Bolibruchova, D.; Žihalová, M. Vanadium Influence on Iron Based Intermetallic Phases in AlSi6Cu4 Alloy. Arch. Met. Mater. 2014, 59, 1029-1032. [CrossRef]

17. Okamoto, H. Al-Mo (Aluminum-Molybdenum). J. Phase Equilibria Diffus. 2010, 31, 492-493. [CrossRef]

18. Wood, D.M. Coherent epitaxy, surface effects, and semiconductor alloy phase diagrams. J. Vac. Sci. Technol. B Microelectron. Nanometer Struct. 1992, 10, 1675. [CrossRef]

19. Okamoto, H. Al-Cr (Aluminum-Chromium). J. Phase Equilibria Diffus. 2007, 29, 112-113. [CrossRef]

20. Okamoto, H. Mo-Si (Molybdenum-Silicon). J. Phase Equilibria Diffus. 2011, 32, 176. [CrossRef]

21. Smith, J.F. The Si-V (Silicon-Vanadium) system: Addendum. Bull. Alloy. Phase Diagr. 1985, 6, $266-271$. [CrossRef]

22. Guo, Z.; Yuan, W.; Sun, Y.; Cai, Z.; Qiao, Z. Thermodynamic Assessment of the Si-Ta and Si-W Systems. J. Phase Equilibria Diffus. 2009, 30, 564-570. [CrossRef]

23. Venkatraman, M.; Neumann, J.P. The Cr-Mo (Chromium-Molybdenum) system. Bull. Alloy Phase Diagr. 1987, 8, 216-220. [CrossRef]

24. Smith, J.F.; Bailey, D.M.; Carlson, O.N. The Cr-V (Chromium-Vanadium) System. Bull. Alloy Phase Diagr. 1982, 2, 469-473. [CrossRef]

25. Nagender Naidu, S.V.; Sriramamurthy, A.M.; Rama Rao, P. The Cr-W (Chromium-Tungsten) System. Bull. Alloy Phase Diagr. 1984, 5, 289-292. [CrossRef]

26. Zheng, F.; Argent, B.B.; Smith, J.F. Thermodynamic computation of the Mo-V binary phase diagram. J. Phase Equilibria Diffus. 1999, 20, 370-372. [CrossRef]

27. Okamoto, H. V-W (Vanadium-Tungsten). J. Phase Equilibria Diffus. 2010, 31, 324. [CrossRef]

28. Szymczak, T.; Szymszal, J.; Gumienny, G. Statistical Methods Used in the Assessment of the Influence of the Al-Si Alloy's Chemical Composition on its Properties. Arch. Foundry Eng. 2018, 18, 203-211. 
29. Szymczak, T.; Szymszal, J.; Gumienny, G. Evaluation of the Effect of the Cr, Mo, V and W Content in an Al-Si Alloy Used for Pressure Casting on its Proof Stress. Arch. Foundry Eng. 2018, 18, 105-111.

30. Szymczak, T.; Szymszal, J.; Gumienny, G. Evaluation of the Effect of Cr, Mo, V and W on the Selected Properties of Silumins. Arch. Foundry Eng. 2018, 18, 77-82.

31. Nývlt, J. Kinetics of nucleation in solutions. J. Cryst. Growth 1968, 3-4, 377-383. [CrossRef]

32. Nemdili, L.; Koutchoukali, O.; Mameri, F.; Gouaou, I.; Koutchoukali, M.; Ulrich, J. Crystallization study of potassium sulfate-water system, metastable zone width and induction time measurements using ultrasonic, turbidity and 3D-ORM techniques. J. Cryst. Growth 2018, 500, 44-51. [CrossRef]

33. Chai, G.; Bäckerud, L.; Rolland, T.; Arnberg, L. Dendrite coherency during equiaxed solidification in binary aluminum alloys. Met. Mater. Trans. A 1995, 26, 965-970. [CrossRef]

34. Gumienny, G.; Kacprzyk, B.; Gawroński, J. Effect of Copper on the Crystallization Process, Microstructure and Selected Properties of CGI. Arch. Foundry Eng. 2017, 17, 51-56. [CrossRef]

35. Pezda, J. Effect of The T6 Heat Treatment On Change Of Mechanical Properties Of The AlSi12CuNiMg Alloy Modified With Strontium. Arch. Met. Mater. 2015, 60, 627-632. [CrossRef]

36. Władysiak, R.; Kozuń, A.; Dębowska, K.; Tadeusz, P. Analysis of Crystallization Process of Intensive Cooled AlSi20CuNiCoMg Alloy. Arch. Foundry Eng. 2017, 17, 137-144. [CrossRef]

37. Pisarek, B. Model of Cu-Al-Fe-Ni Bronze Crystallization. Arch. Foundry Eng. 2013, 13, 72-79. [CrossRef]

38. Rapiejko, C.; Pisarek, B.; Tadeusz, P. Effect of Cr and V Alloy Additions on the Microstructure and Mechanical Properties of Am60 Magnesium Alloy. Arch. Met. Mater. 2014, 59, 761-765. [CrossRef]

39. Kacprzyk, B.; Szymczak, T.; Gumienny, G.; Klimek, L. Effect of the Remelting on Transformations in Co-Cr-Mo Prosthetics Alloy. Arch. Foundry Eng. 2013, 13, 47-50. [CrossRef]

40. Belov, N.A.; Eskin, D.G.; Aksenov, A.A. Multicomponent Phase Diagrams: Applications for Commercial Aluminum Alloys; Elsevier: London, UK, 2005.

41. Glazoff, M.V.; Khvan, A.V.; Zolotorevsky, V.S.; Belov, N.A.; Dinsdale, A.T. Casting Aluminum Alloys; Elsevier: Oxford, UK, 2019.

42. Pietrowski, S. Al-Si Alloys; Lodz University of Technology Publishing House: Lodz, Poland, 2019.

43. Hurtalová, L.; Tillová, E.; Chalupová, M.; Duriníková, E. Effect of Chemical Composition of Secondary Al-Si Cast Alloy on Intermetallic Phases. In Machines, Technologies, Materials, Proceedings of the 9th International Congress, Varna, Bulgaria, 19-21 September 2012; pp. 23-26. Available online: https://scholar.google.com.hk/scholar?hl=en\&as_sdt=0\%2C5\&q=Effect+of+Chemical+Composition+ of + Secondary $+\mathrm{Al}-\mathrm{Si}+$ Cast+Alloy+on+Intermetallic + Phases\&btnG= (accessed on 22 September 2020).

44. Tillová, E.; Závodská, D.; Kuchariková, L.; Chalupová, M.; Belan, J. Study of Bending Fatigue Properties of Al-Si Cast Alloy. Arch. Met. Mater. 2017, 62, 1591-1596. [CrossRef]

45. Kuchariková, L.; Tillová, E.; Matvija, M.; Belan, J.; Chalupová, M. Study of the precipitation hardening process in recycled Al-Si-Cu cast alloys. Arch. Met. Mater. 2017, 62, 397-403. [CrossRef] 